\title{
DISTORSI BENTUK IMAJINER UNTUK PENCAPAIAN
} HARMONI

I Made Bendi Yudha

Fakultas Seni Rupa ISI Denpasar

\section{Abstract}

Art is an expression of feeling and soul. It is the crystallization of an idea that derives from imaginative soul experience through observation, deep thinking on the phenomena of social environment. Then, through intellectual ability and internal or external motivation raises an intuitive vibration that stimulates inner emotion to be artistically expressed through the language of visual art work.

For Balinese, rerajahan is one of literature works which has a value and symbolic meaning of the all life aspects both on macro and micro cosmo It is also depicting the energy that is a symbol of gods and evil character. These all are the reflection of dualistic. These concepts which are overlapping and interdependent to each other must be kept appropriately in order to maintain the harmony.

$$
\text { The concept of harmony that exists in rerajahan seems neglected or }
$$
even left behind when we compare with the phenomentife in society. even left been on the in we cop can be seen on the inappre know, an explo particular parties or people, gender, discrimination on law and human rights, and inappropriate acts of state administration.

These phenomena generally make the increase of ecological crisis and the degradation of human moral or get the level of social poverty even worse. At present, these inappropriate acts are getting out of control because the spread takes place both on the low and elite levels. So, these are very complex phenomena just like a messy thread that needs to be solved holistically. The comprehension of all the above values have brought some ideas regarding on the life meanings in which its philosophical concepts in an abstract way astatically are implemented into the painting art work by combining both the representative and abstractive concepts. It is also implemented in term of applying varied line, color abstrive . It is hope that impasto technique can reppent and texes. it is he the an meaning in order to give the value of the authenticity of the art work which has an
artistic personal values and novelty.

Key word : Painting art work, distortion of imaginary shape and harmony

\section{PENDAHULUAN}

Latar Belakang

Seni adalah ungkapan perasaan dan gejolak jiwa, merupakan kristalisasi ide-ide yang bersumber dari pengalaman imajinatif sebagai daya kepekaan rasa, berdasar atas pengamatan, perenungan terhadap fenomena-fenomena yang terjadi di lingkungan masyarakat. Kemudian dengan kemampuan inteleksi dan dorongan 
internal, muncul getaran-getaran intuitif yang menstimulasi emosi untuk diekspresikan secara artistik melalui bahasa visual seni lukis.

Selain itu seni juga merupakan pencarian jawaban atas persoalan yang mempertanyakan keadaan. Hal-hal seperti ini merupakan bukti bahwa motivasi atau dorongan kelahiran karya seni tidak dapat lepas dari kebutuhan manusia. Bagaimana pun ekspresinya atau individualitasnya seorang seniman, ia tetap membutuhkan manusia lainnya untuk menikmati hasil karyanya, karena suatu karya seni terlahir memang untuk dinikmati baik untuk kebutuhan lahiriah maupun batiniah (Sunarya, 2002: 2).

Dalam menciptakan karya seni, seniman tidak bisa lepas dari pengaruh lingkungannya seperti misalnya; agama, budaya, adat-istiadat dan lain sebagainya, oleh sebab itu setiap karya seni akan mencerminkan latar belakang nilai-nilai budaya masyarakatnya, dan merupakan kenyataan yang langsung dihadapi sebagai rangsangan atau pemicu kreativitas kesenimannya. (Sumardjo, 2000: 133).

Seorang seniman sebagai bagian dari suatu komunitas masyarakat, berusaha belajar tentang kehidupan dari masyarakat, dididik oleh tata nilai masyarakatnya, dan mengkondisikan dirinya dengan nilai-nilai yang ada di dalamnya. Karena pada dasarnya seorang seniman bekerja berdasarkan pengaruh teks dan pemahaman karya seni yang terdapat dalam tradisi masyarakatnya (Sumardjo, 2000: 234).

Sebagaimana halnya yang terjadi pada pencipta dalam melakukan aktivitas berkesenian, ternyata fenomena-fenomena sosial, budaya, agama, adatistiadat serta keindahan alam Bali yang mempesona telah menggetarkan hati dan perasaan, merasuk menembus batas-batas ruang imajinasi, kemudian secara virtual memprovokasi aktivitas intuisi yang memicu potensi kreatif, sehingga terobsesi untuk menjelmakannya ke dalam bahasa rupa.

Bali menjadi salah satu tujuan kunjungan utama bagi wisatawan domestik maupun mancanegara, disebabkan di samping karena keindahan alamnya yang mempesona, juga karena agama, seni, dan adat-istiadat menjadi bagian yang integral dalam kehidupan bermasyarakat. Hal tersebut berdampak pada munculnya berbagai bentuk karya seni dan budaya yang memiliki nilai-nilai eksotik tinggi, serta hal ini pula telah membawa dampak terhadap terjadinya perubahan yang signifikan bagi kehidupan masyarakat Bali, terutama dalam ajang interaksi global melalui media komunikasi dan informasi yang semakin canggih.

Problematik yang dihadapi masyarakat Bali sebagai dampak dari interaksi tersebut, adalah terjadinya akulturasi budaya dari berbagai suku bangsa di dunia dengan keragaman budayannya, dan akhirnya tanpa disadari telah memasuki budaya progresif serta ingin mengejar ketertinggalannya di segala sektor kehidupan, untuk mengantisipasi persaingan global yang selektif kompetitif.
Dampak dari pengaruh tersebut telah membawa kemajuan dan perubahan yang signifikan terhadap nilai-nilai budaya masyarakat Bali, termasuk di dalamnya pola pikir dan pola tindak yang tercermin dari cara pandang dan mentalitasnya yang lebih cenderung materialistik dan individual. Hal tersebut sudah tentu berimplikasi pada terjadinya distorsi/penyimpangan serta perbedaan pandangan terutama menyangkut; agama, sosial-budaya, ekonomi, lingkungan alam, politik dan sebagainya.

Distorsi terhadap konservasi dan eksistensi alam di berbagai belahan dunia, hingga kini dirasakan sangat mengkhawatirkan kelangsungan ekosistem yang ada, dan telah menjadi persoalan rumit dan krusial bagi semua bangsabangsa di dunia,

“... ketika sebagian besar dari lembaga sosio-ekonomi masyarakat industrial modern didasarkan pada usaha mengejar kemajuan material melalui keterpisahan dari dan sikap menaklukkan alam (Tucker \& Grim, 2003: 125-126). Akhirnya terjadi desakralisasi alam di mana alam dipandang sebagai sesuatu yang harus digunakan dan dinikmati semaksimal mungkin, dikuras hingga ke tingkat yang mustahil (Nasr, 1984: 28-29).

Di samping perlakuan distorsif terhadap alam, pada tataran kehidupan dan interaksi sosial masyarakat pada umumnya, tindakan-tindakan penyimpangan yang cenderung merugikan kepentingan masyarakat secara umum telah terjadi, baik di kalangan tingkat bawah, menengah bahkan sampai pada kalangan tingkat atas penentu kebijakan. Sebagaimana diketahui telah terjadinya penyimpangan dan penyalahgunaan kekuasaan oleh pihak-pihak dan oknum tertentu yang berkuasa, diskriminasi di bidang hukum dan HAM, jender, penyalahgunaan hak maupun kewenangan di bidang administrasi negara dan lain sebagainya.

Persoalan-persoalan ini apabila tidak disikapi dengan penuh kearifan niscaya akan dapat menimbulkan terjadinya disharmoni, yang bermula dari munculnya konflik kepentingan baik vertikal maupun horisontal, kemudian melahirkan tindakan-tindakan anarkis yang dapat mengancam keutuhan negara dan bangsa. Fenomena semacam ini nampaknya telah menjadi isu global, yang memerlukan konseptor dari berbagai disiplin ilmu dalam kerangka ikut mengatasi persoalan dunia, guna menemukan solusi terbaik dalam menghadapi krisis multidimensional tersebut.

Distorsi bentuk imajiner untuk mencapai harmoni dalam hal ini adalah berbagai distorsi/penyimpangan yang terjadi dalam kehidupan bermasyarakat dalam memenuhi kebutuhan hidup duniawi untuk mencapai kemajuan material. Dalam konteks ini hendaknya dilandasi oleh pemahaman nilai-nilai spiritual, sebagai prinsip dasar dalam menjaga keseimbangan dan keharmonisan hidup lahir 
maupun batin. Hal ini tersirat pada bentuk-bentuk Rarajahan Bali, dan tergambar dengan jelas yaitu adanya tulisan/kaligrafi Bali maupun figur-figur tokoh yang menunjukkan karakter sifat yang berbeda dan saling bertentangan antara yang satu dengan yang lainnya. Bentuk-bentuk yang digambarkan terkadang menyimpang dari bentuk-bentuk nyata, karena merupakan abtraksi dari apa yang ada di alam, seperti misalnya: bentuk dewa-dewa, raksasa (bhuta kala), stilisasi bentuk manusia, gambar binatang digabung dengan gambar khayalan menyerupai totem-totem, kemudian diberi makna sesuai dengan karakter tokoh yang diinginkan.

Dari hasil pengamatan tersebut timbul penafsiran suatu makna bahwa, kepurbaan manusia di dalam mememenuhi kebutuhan hidupnya di dunia ini, pada dasarnya memiliki dua potensi serta peluang yang saling tarik-menarik yaitu; melakukan strukturisasi yang berorientasi pada kebajikan, dan melakukan distorsi/penyimpangan-penyimpangan yang cenderung merusak tatanan yang ada serta merugikan orang lain. Hal ini bila pengelolaannya tidak didasari pada nilai-nilai kebajikan dan kebenaran serta mengacu pada konsep keseimbangan dan keharmonisan, maka hal tersebut akan berpengaruh terhadap tatanan sosial masyarakat yang rentan akan ancaman konflik dan perpecahan sehingga dapat menggoyahkan sendi-sendi keutuhan berbangsa dan bernegara.

Pengamatan dan penghayatan terhadap bentuk-bentuk Rarajahan Bal yang sering digunakan pada setiap aktivitas ritual masyarakat Bali merupakan suatu pengalaman interaktif dalam kehidupan sosial budaya, yang dijadikan sebagai subjekmatter, telah memberikan dorongan imajinatif sebagai pemicu terhadap munculnya aktivitas kreatif.

“...bahwa dengan keseniannya manusia mengekspresikan pengalaman keindahan atau estetik. Jiwa yang penuh getaran, hati yang terharu, penuh rayuan yang mesra, itulah yang melahirkan kesenian (Driyarkara, 1990: 8).

Berdasar atas pengalaman estetik dari merespon esensi serta makna yang terkandung dalam bentuk-bentuk Rarajahan tersebut, telah memberikan stimulan untuk memunculkan sebuah gagasan/ide-ide kreatif kemudian diekspresikan ke dalam karya seni lukis.

Eksplorasi yang dilakukan melalui hasil pengamatan terhadap bentukbentuk Rarajahan Bali, dapat dijadikan sebagai pengembangan inteleksi dan intuisi untuk membangkitkan imajinasi dengan memaknai karakter dan distorsi bentuk, motif, tema, simbol-simbol dan keindahan lainnya. Dengan ini pula muncul interpretasi serta pemahaman, bahwa secara simbolik tercermin nilainilai tentang falsafah kehidupan yang ambigu (dualistik), serta senantiasa berorientasi pada prinsip-prinsip/konsep keseimbangan dan keharmonisan hidup dalam mencapai suatu tujuan.
Secara kontekstual hal tersebut telah memberikan inspirasi untuk menyikapi fenomena yang terjadi dalam kehidupan masyarakat saat ini, betapa tindakan-tindakan distorsif telah dijadikan sebagai suatu cara yang ampuh untuk mencapai suatu tujuan guna memenuhi kebutuhan duniawi. Apabila cara-cara tersebut tidak diantisipasi secara dini dengan penuh kesadaran diri untuk mewujudkan keseimbangan dan keharmonisan, akan berakibat pada semakin besar dan meluasnya persoalan baru yang semakin kritis, sampai pada tingkat krisis ekologis, sosial budaya dan sebagainya.

Dengan mencermati serta mengkaji fenomena yang ada menyangkut isu yang berkembang saat ini, pengalaman tersebut memiliki urgensi yang sangat signifikan untuk di wujudkan ke dalam karya seni lukis. Melalui pemanfaatan elemen-elemen visual seni lukis serta prinsip-prinsip penyusunannya yang disusun sedemikian rupa, sehingga diharapkan dapat mencapai kompleksitas dan estetika karya. Dalam pencapaian tersebut tentunya penekanannya lebih terfokus pada aspek kesatuan dan harmoni, agar dapat menghadirkan ekpresi pribadi serta nilai-nilai kekinian seni lukis.

\section{Keaslian Penciptaan}

Seniman adalah sosok pribadi, oleh karena itu sebagai individu dia akan selalu memperjuangkan nilai-nilai subjektifitas yang bersumber dari pengalaman pribadinya sehingga dalam setiap hasil karyanya akan tercermin nilai-nilai tersebut sebagai ungkapan pribadi dalam proses perjalanan berkeseniannya. Sebagaimana yang diungkapkan oleh Sumardjo (2000: 183), bahwa, “...nilai-nilai subyektif yang amat khas pada seorang individu itu bekerja dalam kepentingan atau tekanan yang berbeda-beda selama proses pengalaman seninya. Dan inilah yang melahirkan kesimpulan akhir dari pengalaman seni bagi setiap orang". Ini berarti bahwa kreativitas yang mampu melahirkan keaslian atau orisinalitas dengan segala keunikannya, merupakan unsur yang sangat penting bagi sebuah proses pengalaman seninya, sebagai cermin dari subyektifitas senimannya.

Orisinal adalah buah dari proses kreatif yang melibatkan perenungan secara mendalam serta menghindari peniruan secara buta (peniruan semata-mata demi peniruan) yang bertujuan meniru suatu obyek sepersispersisnya. sebuah karya seni dianggap orisinal jika pokok persoalan bentuk dan gaya yang ditampilkan adalah baru (Sumartono, 1992: 2).

Berkaitan dengan uraian di atas, keaslian yang ditawarkan dalam penciptaan ini meliputi dua persoalan besar yaitu proses kreatif menyangkut visualisasi karya dan isi karya secara konsepsual. Persoalan yang menyangkut visualisasi karya yang mengacu pada tema dimaksud di atas, diwujudkan menjadi karya seni lukis dengan menerapkan elemen-elemen warna akrilik yang 
digoreskan dengan teknik sapuan kuas dan kerokan pisau palet yang bervariatif/tumpangtindih. Upaya ini dilakukan dalam usaha memunculkan efekefek artistik dari brush stroke/ sapuan kuas, sehingga dicapai tekstur yang padat dan terkesan empuk sebagaimana teknik impasto yang diinginkan. Visualisasi bentuk karya cipta lebih difokuskan pada kombinasi antara bentuk-bentuk representatif (realistik) dengan abstrak, sebagai representasi dari kehidupan manusia yang tidak terlepas dari pemikiran yang dualisme, yaitu: antara yang nyata dengan yang abstrak, materi dan spiritual, sifat baik dan buruk, dan sebagainya. Sedangkan pada isi karya, tema di atas sebagai sebuah imaji dari jejak-jejak makna, dimaksudkan dapat menampung dan mengakumulasikan berbagai pencitraan dalam dimensi tempat, ruang, waktu maupun keadaan yang selalu bergerak mengikuti iramanya. Hal tersebut bisa saja tentang filosofis kehidupan, manusia, konflik, percintaan, penyadaran, dan lain-lain, di mana dalam pengekspresiaannya berorientasi pada nilai-nilai pencerahan untuk memahami serta memaknai arti kehidupan.

Sebagai komparasi dalam proses penciptaan ini, mengambil salah satu karya I Made Budhiana yang ide-ide karyanya juga terinspirasi oleh bentuk Rarajahan Bali untuk menyikapi problematik kehidupan saat ini, menyangkut hal-hal yang abstrak yang dia bisa nikmati dalam hidup sehari-hari. Ia seringkali hanyut dalam kondisi-kondisi umum kemudian merespons sekadarnya atas riak yang terjadi di luar dirinya, yaitu suatu keadaan di mana antara ancaman dan harapan sungguh tak jelas bentuknya, yang mengharuskan panggilan hatinya untuk melihat, berbuat, dengan suka hati dan menarik dirinya dari realitas kasat mata ke realitas imaji. Maka pada kanvas yang kosong, serakan garis dan warna adalah pengendapan pengalaman estetik yang selama ini tersimpan dalam dirinya, mengalir menjadi bentuk-bentuk-bentuk imajinatif sebagai bahasa ungkap yang dijelmakan pada karya-karyanya (Budhiana, 2001).

Dalam hal ini Budhiana menangkap esensi dari Rarajahan yang kemudian dimaknainya untuk menyikapi fenomena kehidupan saat ini ke dalam bahasa simbol dengan memadukan kekuatan garis dan warna yang dimiliki sehingga menemukan bentuk-bentuk imajinatif yang cenderung abstraksi-abstrak. Artinya karya-karya yang merupakan olahan dari obyek-obyek atau gagasan pelukisnya, kemudian divisualisasikan dalam bentuk abstrak (Wisetrotomo, 1998:32).

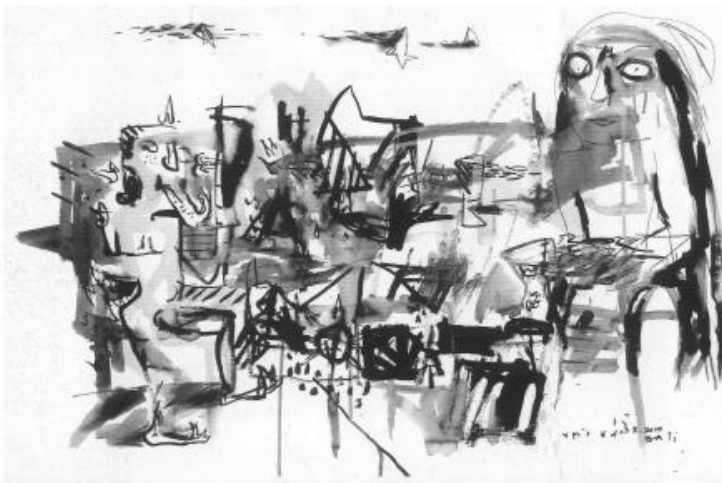

Gambar: 1 Dialog, 2000, karya I Made Budhiana., Media campuran pada kertas Ukuran, $75 \mathrm{~cm}$ x 56 cm (Sumber: Katalogus, "12 Painters of Sanggar Dewata")

Sedangkan pada karya-karya penulis mengutamakan aspek nilai-nilai filosofis kehidupan yang terkandung dalam rarajahan. Aspek bentuk pada bahasa ungkap diwujudkan ke dalam bentuk yang representatif dan bentuk abstraktif untuk mencapai konsep distorsi bentuk yang diinginkan, dengan aktualisasi karya mengacu pada pencitraan nilai-nilai simbolik tentang kehidupan, melalui terjemahan figur-figur yang kontradiktif. Dengan demikian, secara keseluruhan karya-karya dengan tema tersebut di atas dipandang telah memiliki nilai keaslian dan kebaruan (novelty) dalam melakukan kontemplasi serta pengekspresian yang unik individual.

\section{KONSEP PENCIPTAAN}

\section{Kajian Sumber Penciptaan}

Untuk lebih memantapkan konsep terutama dalam membentuk struktur karya yang memiliki landasan yang kuat dalam penciptaan ini, perlu dilakukan pengkajian terhadap sumber-sumber acuan yang dijadikan pedoman dalam menstimulasi sensibilitas, sehingga dapat membangkitkan pengalamanpengalaman estetik. Pengalaman tersebut diharapkan dapat memberikan getarangetaran intuitif yang dapat mendorong emosi dan imajinasi kreatif.

Adapun referensi yang dujadikan sumber acuan adalah; sumber kepustakaan, hasil observasi berupa penjelajahan dan pengamatan serta kontemplasi, terhadap objek-objek tertentu yang dapat memberikan rangsangan imajiner terhadap proses penciptaan karya seni lukis. Pengalaman estettik timbul atas reaksi positif terhadap pemaknaan suatu fenomena yang terjadi disekitar kita, seperti yang diungkapkan oleh Hartoko (1984: 12), bahwa:

Dalam kesenian dan pengalaman estetik itu budi manusia memainkan peranan utama, tetapi bukan budi yang diskursif (yang menganalisa dan 
bernalar), melainkan yang bersifat intuitif (melihat dalam sekejap mata) dan konotural (karena persamaan dalam sifat dan tabiat). Terjadi semacam interpenetrasi (saling menerobos) antara alam dengan manusia. Kedua belah pihak saling meluluh tanpa kehilangan identitasnya masing-masing. Manusia yang merasakan getaran keindahan alam mengadakan semacam identifikasi spiritual dengan alam itu, bahkan alam memasuki kalbunya. Dan sebaliknya: manusia memasuki alam, memeteraikan alam dengan kehadirannya, merasakan keindahan alam itu sejauh alam mengandung unsur-unsur manusiawi, mengandung syarat-syarat yang melambangkan emosi dan pengalaman manusia.

Melalui pengamatan dan eksplorasi yang dilakukan terhadap rarajahan Bali, kemudian dikaitkan dengan fenomena kehidupan masyarakat dewasa ini, tercetuslah ide-ide kreatif sebagai konsep dasar penciptaan seni lukis, dengan topik "Distorsi Bentuk Imajiner untuk Mencapai Harmoni”.

\section{Pengertian Distorsi}

Pengertian distorsi yang berkaitan dengan penciptaan karya seni diartikan sebagai suatu kemampuan seseorang/seniman dalam melakukan pengolahan objek yang menyebabkan terjadinya perubahan/penyimpangan wujud sesuai dengan selera senimannya. Seperti yang diuraikan oleh Kartika (2004: 42), menyebutkan bahwa:

Distorsi adalah penggambaran bentuk yang menekankan pada pencapaian karakter dengan cara menyangatkan wujud-wujud tertentu pada benda atau objek yang digambar, misalnya pada penggambaran tokoh figur Gatutkaca pada wayang kulit purwa yang digambarkan dengan figur serba mengecil. demikian juga pada penggambaran topeng raksasa dengan warna merah, mata melotot, untuk menyangatkan bentuk karakter figur tokoh angkara murka. Sehubungan dengan pendapat di atas, distorsi yang dimaksud dalam penciptaan seni lukis ini adalah; penggambaran bentuk-bentuk yang menekankan pada pencapaian karakter dari figur-figur berupa manusia, binatang atau pun benda-benda yang ada disekitarnya, kemudian dengan melakukan berbagai pengolahan dan perubahan bentuk, lalu ditata sedemikian rupa agar dapat mewakili simbol tertentu sehingga dapat memenuhi ide-ide yang diinginkan.

\section{Pengertian Bentuk}

Dalam Kamus Besar Bahasa Indonesia, bentuk berkonotasi kata benda yang berarti rupa, sedangkan dalam bahasa Inggris disebut form. Kemudian menurut Burke dalam buku "Art As Image And Idea" atau "Seni Sebagai Ujud dan
Gagasan” terjemahan SP. Gustami (1991:28-29), menyebutkan sebagai berikut: Bentuk adalah "manifestasi fisik luar dari suatu obyek yang hidup, tetapi bidang adalah " manifestasi dari suatu obyek yang mati. Hasil berbagai bentuk dapat memiliki kualitas linier jika perhatian kita diarahkan pada batas- batas mereka, tetapi kontur-kontur itu biasanya mempunyai efek membuat kita menyadari bentuk, yakni mereka menghadirkan warnawarna silhouette pada bidang atau ruang yang mereka pagari.

Sedangkan Djelantik (2001: 18), menegaskan bahwa, bentuk yang paling sederhana adalah titik. Titik sendiri tidak mempunyai ukuran atau dimensi. Titik sendiri belum mempunyai arti tertentu. Kumpulan dari beberapa titik yang ditempatkan di area tertentu akan mempunyai arti. Kalau titik-titik berkumpul dekat sekali dalam suatu lintasan titik akan membentuk garis. Beberapa bidang bersama akan membentuk ruang. Titik, garis, dan ruang merupakan bentukbentuk yang mendasar bagi seni rupa.

Berdasar atas uraian tersebut, sehubungan dengan penciptaan seni lukis ini, akan mengetengahkan bentuk sebagai manifestasi fisik dari obyek-obyek yang memberikan rangsangan ide-ide. Dalam visualisasi objek akan muncul bentuk-bentuk yang representatif dan bentuk-bentuk abstrak sebagai cerminan dari dualisme kehidupan yang selalu saling melengkapi. Bentuk-bentuk di sini di samping untuk mewakili kenyataan-kenyataan atas fenomena yang terjadi, juga sebagai upaya untuk mencari dan menemukan simbol-simbol baru yang representatif dengan pencapaian ide-ide, kemudian diwujudkan ke dalam seni lukis.

Secara menyeluruh dari berbagai hubungan tersebut telah memberikan konstribusi kreatif dalam mengartikulasikan ide-ide, sehingga dapat dijadikan sebagai sarana untuk mengekspresikan pencitraan karakter objek dengan menggunakan simbol-simbol baru, sedangkan fenomena alam, dan fenomena sosial dicitrakan melalui pemahaman ilusi-ilusi dan pikiran.

\section{Konsep Imajinasi}

Istilah imajinasi berawal dari kata imaji, ini kadang dipakai untuk menterjemahkan kata Yunani eidolon, sebagaimana dalam Demokritos dan Epikuros yang menyebut kerangka-kerangka yang dikirim oleh obyek-obyek kepada panca indera kita dalam persepsi. (Bagus, 2002: 316).

Secara terminologi umumnya yang dimaksud dengan istilah imaji adalah "daya untuk membentuk gambaran (imaji) atau konsep-konsep mental yang tidak secara langsung didapat dari sensasi (Pengindraan)". Imaji adalah suatu daya, dan karenanya, imaji itu berkaitan langsung dengan manusia yang memiliki daya tersebut. Secara umum pula dapat dipahami bahwa hanya manusialah yang 
memiliki daya, bukan makhluk hidup yang lainnya (Tedjoworo, 2001: 21). Lebih lanjut ditegaskan bahwa:

..., proses mengimajinasikan itu selalu merupakan proses membentuk gambaran tertentu, dan ini terjadi secara mental. Artinya, gambaran tersebut tidak berada secara visual (tampak oleh mata) dan tektural (terasa serta teraba oleh tangan dan kulit). Sebuah lukisan adalah imajinasi seorang pelukis. Namun lukisan yang kita lihat dan (mungkin) kita raba itu tidak sama dengan imaji yang muncul tatkala sang pelukis berimajinasi. Lukisan itu adalah apa yang dihasilkan oleh proses imajinasi yang tertuang dalam kombinasi tertentu goresan cat minyak pada kanvas. Dengan begitu lebih jelaslah bahwa istilah imajinasi umumnya diterapkan pada suatu proses mental, bukan pada proses visual-jasmaniah yang dilakukan seketika itu juga oleh manusia. Namun kelak akan tampak bahwa proses visualisasi-jasmaniah tertentu dapat diimajinasikan, meskipun imajinasi tetap tidak sama dengannya (2001: 21-22).

Aristoteles mengkonsentrasikan diri pada pemahaman imajinasi sebagai suatu representasi mental (phantasma). Sebagai presentasi mental, imajinas bertugas menjembatani sensasi dan rasio. Oleh karenanya, semua imaji serta gambaran mental yang kita miliki kita dapatkan dari pengalaman melalui sensasi, yang kemudian dibawa kepada rasio melalui imajinasi. Sehubungan dengan itu ditegaskan pula bahwa,... "dengan mengacu kepada keberadaannya (einai), imajinasi dan sensasi sama saja (Tedjoworo, 2001: 33).

\section{Pentingnya Imajinasi}

Kekuatan imajinasi memainkan peranannya yang sangat penting sebagai imajinasi kreatif . Ini penting untuk pemikiran yang produktif, untuk inspirasi yang penting bagi ilmu pengetahuan, seni, teknik dan agama. Dalam halnya manusia, semua pikiran baru secara alamiah membutuhkan bantuan imajinasi dengan kebebasannya untuk bermain mengitari ide-ide. Tentu saja inspirasi baru harus diuji dengan teliti dan di tes sungguh-sungguh, karena unsur irasional dalam menggunakan imajinasi dapat menghasilkan baik sesuatu yang omong kosong maupun seorang jenius.

Dalam bidang ilmu pengetahuan, imajinasi membantu ilmuwan untuk mengetahui dunia dengan memasukan hipotesis, konsepsi, gagasan untukbereksperimen. Dalam bidang seni, imajinasi memegang peranan penting secara istimewa. Bagi seorang seniman, imajinasi tidak hanya membantunya untuk suatu generalisasi, tetapi sebagai kekuatan yang memanggilnya aga menghidupkan gambar-gambar seni yang penuh arti, yang mencerminkan realitas secara artifisial (Bagus, 2002: 319).
Pengertian imajinasi yang dimaksud dalam penciptaan seni lukis ini, adalah suatu upaya pencapaian gambaran (imaji) atau konsep-konsep mental yang tidak secara langsung didapat dari sensasi-sensasi pengindraan dari suatu fenomena yang dijadikan sebagai subjek matter. Imaji adalah suatu proses spontanitas yang secara spontan juga menciptakan maknanya sendiri, hal ini diupayakan untuk mendapatkan esensi dan karakter dari objeknya melalui pengamatan, perenungan/kontemplasi terhadap endapan pengalaman estetik yang dimiliki.

\section{Tinjauan Tentang Rarajahan}

Di Bali rarajahan hampir selalu digunakan dalam kaitannya dengan upacara keagamaan yang lebih dikenal dengan Panca Yadnya, yaitu lima bentuk korban suci yang dilakukan dengan tulus ikhlas, di mana bentuk-bentuk rajah tersebut tidak hanya berbentuk huruf-huruf, tetapi bermacam-macam wujud benda baik bergerak maupun tidak bergerak, benda mati maupun benda hidup dan lain-lain.

Sebagaimana yang diuraikan oleh Ginarsa (1979) sebagai berikut: Pertama berupa tulisan atau kaligrafi Bali, kedua berupa stilisasi dari bentuk manusia, ketiga berupa gambar-gambar binatang yang digabung dengan gambar khayalan. Sedangkan Jaman dalam Titib (2001: 480), mengkelompokkan meliputi; (1), Rarajahan berbentuk huruf-huruf terutama huruf-huruf suci atau Vijaksara mantra, kutamantra maupun mantram yang singkat. Vijaksara tersebut meliputi : Omkara simbol Tuhan Yang Maha Esa (Brahman), Am (simbol Brahma). (2), Rarajahan ini banyak digunakan terutama pada waktu upacara Panca Yadnya, misalnya upacara Dewa Yadnya, Pitra Yadnya, Manusa Yadnya, Bhuta Yadnya, dan upacara Rsi Yadnya. (3), Rarajahan berbentuk benda-benda langit seperti matahari, bulan dan bintang yang dikombinsikan dengan hurufhuruf suci, vijaksara, dan senjata dewa-dewa. (4), Rarajahan berbentuk bunga terutama bunga padma atau teratai, sering pada masing-masing kelopak daunnya dirajah dengan huruf-huruf suci vijaksara. (5), Rarajahan berbentuk binatang seperti harimau, singa, ular atau naga, ikan laut, ulat dan lain-lain. (6), Rarajahan berbentuk dewa-dewa, lengkap dengan masing-masing dewi (sakti)-Nya, kendaraan (tunggangan)- Nya, senjata-Nya, posisi-Nya pada tubuh manusia, warna dan penjuru yang dikuasainya. (7), Rarajahan berbentuk manusia, manusia berkepala binatang, binatang berkepala manusia, anggota badan manusia seperti manusia tanpa kepala, kepala tanpa badan, tangan berkepala manusia, kaki berkepala manusia dan sebagainya. (8), Rarajahan berbentuk raksasa lengkap dengan senjatanya, warna dan lain-lain, serta yang terakhir adalah rerajahan berbentuk bangunan suci seperti meru. 
Sehubungan dengan jenis bentuk-bentuk yang ada pada rarajahan Bali, apabila dikaitkan dengan fungsi dari masing-masing bentuk rarajahan tersebut, dapat dikelompokkan antara lain; (1), Untuk mendapatkan kekuatan dan perlindungan dari para dewata. (2), Untuk menyucikan pribadi seseorang. (3), Untuk memperoleh kekuatan gaib dari kekuatan alam. (4), Untuk memperoleh simpati "pamatuh", dan menghentikan tindakan seseorang yang jahat. (5), Mencegah dan menangkal hal-hal yang tidak disukai yang dapat membahayakan seseorang, (6), Mengembalikan usaha pihak musuh untuk mencelakakan diri seseorang dengan kekuatan sihir dari rarajahan, sehingga menyebabkan pihak musuh meninggal.

Berdasarkan bentuk-bentuk dan fungsi yang terdapat pada rarajahan Bal sebagaimana yang diuraikan di atas, dapat ditangkap makna yang terkandung di dalamnya bahwa, kehidupan yang ada pada makrokosmos (alam besar) dan mikrokosmos (alam kecil), memiliki dua sifat yang berlawanan yaitu sifat dewa dan sifat bhuta, sebagai cerminan dari konsep dualistis yang merupakan dua pasangan berbeda, yang harus selalu ada dalam posisi seimbang. Ini berarti bahwa kehidupan manusia dalam mengarungi bahtera kehidupan ini, hendaknya senantiasa mampu mengelola potensi diri yang bersumber pada dua kekuatan besar, baik yang ada di dalam maupun di luar dirinya, sehingga keduanya dapat bekerja dengan baik secara sinergis, untuk mencapai suatu tujuan yaitu keseimbangan hidup lahir dan batin. Berkaitan dengan ini I Ketut Sunarya (2001: 92) menjelaskan bahwa:

Konsep dualistis atau rwa bhineda tercermin juga dalam bentuk rajah yaitu bala dan penolak bala. Rajah bala yaitu rajah yang diyakin masyarakat Hindu di Bali sebagai jimat membuat penyakit, sedangkan rajah penolak bala diyakini sebagai pengayom atau menjaga dari serangan bala. Kemunculan rajah terkait dengan keinginan masyarakat menciptakan keharmonisan dan keseimbangan baik secara sekala (jagat raya ini) maupun niskala (alam abstrak). “... dengan rajah pengeleakan atau pendestian yang disebut juga dengan bala atau ilmu hitam, ilmu kir yang mempunyai tugas menyakiti dengan kesaktiannya yang luar biasa. Leak adalah sifat dan tingkah laku manusia yang berpihak pada kejahatan seperti; ingin menguasai orang lain dengan cara memaksakan kehendak. Dalam kaitannya dengan rajah penolak bala, Tulak dalam Sunarya (2001:

92-93) menjelaskan bahwa; manusia mempunyai keinginan untuk berbuat baik, hal ini menumbuhkan hasrat belajar ilmu pengobatan, dan juga mantra-mantra untuk membersihkan lingkungan sebagai penolak bala dari keletehan (energi negatif) yang disebabkan oleh gangguan roh jahat, salah menempatkan posisi pintu rumah, hubungannya dengan tembok pembatas pekarangan rumah (penyengker) dan sebagainya.

Bentuk lain sebagai penolak bala dilakukan pula oleh pemuka agama, seperti Pemangku, Sulinggih/Peranda dan lain-lain, dengan melakukan upacara yadnya, berupa kurban suci untuk membersihkan/meruat jagat raya ini dari keletehan (energi negatif). Adapun sarana upacara yadnya tersebut dilengkapi dengan rajah penolak bala yaitu goresan berupa simbol-simbol dewa serta mantra-mantra yang dilakukan sesuai dengan tujuan dari rajah tersebut.

Kedua pandangan ini agaknya telah cukup dijadikan acuan dalam menyikapi kehidupan ini yang berada dalam batas ruang dan waktu, untuk melakukan reinterpretasi mengenai kosmos dan jatidiri kita. Sebagaimana yang diungkapkan oleh Atmaja (2003: 9), sebagai berikut:

“... Reinterpretasi ini menjadi penting dan urgen manakala dilihat adanya kesenjangan antara berbagai pandangan bijaksana itu berhenti hanya sebagai wacana yang dengan rajin dikutip dan diucapkan orang di manamana namun dalam kenyataan dan implementasi prilaku kurang menunjukan serta mengejewantahkan nilai kebijakan yang sebenarnya.

Pendapat di atas lebih menegaskan betapa pelaksanaan nilai-nilai kearifan menjadi lebih penting ketimbang harus mengurai wacana, dan perlu dilanjutkan ke tingkat penghargaan/ruang apresiasi untuk bisa menghargai nilainilai yang dikandungnya dengan cara yang tepat dan kontekstual. Artinya nilainilai kehidupan bermasyarakat hendaknya dihargai secara proporsional, dimaksudkan dapat mengejewantahkannya ke dalam prilaku keruangan/interaksi yang didasari dengan sikap penuh kearifan untuk mencapai tujuan hidup yaitu mokhsartam jagadithaya ca iti dharma.

Berdasarkan pengalaman dari mengamati nilai-nila tersebut, telah melahirkan perasaan estetik dan imajinasi bagi munculnya ide-ide kreatif, untuk dijelmakan ke dalam bentuk karya seni lukis, mengingat fenomena yang terjadi dalam kehidupan bermasyarakat saat ini telah dijadikan lahan yang potensial untuk dijadikan ajang pertentangan dan pertikaian dalam mewujudkan kepentingan politik dan kekuasaannya. Hal tersebuti cenderung mengorbankan kepentingan yang lebih luas menyangkut sendi-sendi keutuhan dalam berbangsa dan bernegara, karena telah mengabaikan dan melakukan distorsi terhadap nilai-nilai /tata krama dalam kehidupan bermasyarakat serta keluar dari prinsip-prinsip keseimbangan dan keharmonisan.

\section{Landasan Penciptaan}

Landasan utama dalam penciptaan karya seni lukis ini didorong oleh obsesi yang kuat untuk mewujudkan keharmonisan yang berawal dari pengamatan terhadap bentuk-bentuk rarajahan Bali, yang telah memberikan rangsangan 
imajinatif tentang fenomena kehidupan saat ini. Berdasar atas penghayatan dan perenungan yang dilakukan, lalu tercetus suatu gagasan tentang esensi dari tindakan distorsif dalam kehidupan bermasyarakan, menyangkut segala tindakan/ perilaku yang telah menyimpang dari norma-norma agama, mengabaikan nilai-nilai kebajikan dan kebenaran serta cenderung merugikan kepentingan orang lain menyangkut ahlak hidup orang banyak.

Sebagaimana diketahui bahwa, fenomena kehidupan akhir-akhir ini nampaknya cenderung diwarnai oleh ketegangan-ketegangan/konflik yang terjadi terhadap sesama, penyebabnya tiada lain adalah karena sifat angkara murka manusia dalam memenuhan kebutuhan materinya secara berlebihan, terutama terhadap pemanfaatan sumber daya alam dan manusia dengan melakukan eksploitasi tanpa mengenal prikemanusiaan. Kecenderungan seperti ini tentu akan berdampak pada terjadinya kerawanan sosial, kerusakan lingkungan, munculnya berbagai bencana, diskriminasi terhadap suatu golongan tertentu, pemaksaan kehendak dan lain sebagainya, sehingga menyebabkan disharmoni dalam tatanan kehidupan bermasyarakat. Fenomena tersebut menjadi renungan serta dasar pemikiran untuk mengangkat nilai-nilai filosofis kehidupan bermasyarakat berkaitan dengan keharmonisan, keselarasan, dan keseimbangan, karena nilai-nilai tersebut telah diabaikan dan bahkan ditinggalkan dalam menata kehidupan saat ini. Oleh karena itu untuk menata kembali kehidupan yang serasi, selaras, dan seimbang, perlunya dilakukan evaluasi diri sebagai bahan renungan agar senantiasa berpedoman kepada nilai-nilai moralitas yang mengacu pada kebajikan dan kebenaran. Sebagaimana yang tertuang dalam ajaran agama Hindu yang disebut dengan "Trikaya Parisudha" yaitu tiga dasar perilaku yang harus disucikan yang meliputi; pikiran yang baik (manacika), perkataan yang baik (wacika), dan perbuatan yang baik (kayika). Dengan adanya pikiran yang baik akan timbul perkataan yang baik sehingga mewujudkan perbuatan yang baik pula ( Sudarta, 2001: 53). Demikian juga halnya di lingkungan masyarakat Bali diyakini bahwa perbuatan yang baik (subhakarma) membawa hasil yang baik dan perbuatan yang buruk (asubhakarma) membawa hasil yang buruk (Sudarta, 2001: 18).

Nilai-nilai tersebut di atas hendaknya dapat dipakai sebagai tuntunan di dalam melakukan interaksi baik dalam hubungan vertikal maupun horisontal. Dalam hubungan ini implementasinya sudah tentu lebih mengedepankan sikap toleransi tanpa batas yang disebut dengan "Tat wam asi", karena diketahiu bahwa ia adalah kamu saya adalah kamu, dan segala mahluk hidup adalah sama, sehingga menolong orang lain berarti menolong diri sendiri, dan menyakiti orang lain adalah menyakiti diri sendiri ( Sudarta, 2001: 47). Pemahaman dan penghayatan terhadap nilai-nilai ini, bagi masyarakat Bali telah dijadikan pedoman yang menuntun dan mengarahkan pikiran dan pandangan di dalam melakukan interaksi sosial, sehingga hal ini dianggap sebagai amerta karena telah memberikan kesejukan, kenyamanan serta keharmonisan di segala aspek kehidupan bermasyarakat di lingkungannya.

Hubungan yang selaras antara sesama manusia dengan semesta alam, hendaknya menjadikan pedoman hidup dalam menjaga keharmonisan berlandaskan keiklasan dan kasih sayang untuk mencapai keseimbangan hidup material dan spiritual. Dalam konteks ini, untuk memenuhi kebutuhan yang berorientasi pada kemajuan materi, hendaknya didasarkan juga atas pemahaman "Tri Warga" yaitu tiga aspek nilai yang dijadikan pedoman dalam hidup bermasyarakat. Pertama, Dharma ialah kebenaran yang merupakan dasar dan jiwa dari segala usaha. Kedua, Artha ialah hasil usaha yang merupakan harta benda. tetapi hasil usaha inipun harus didapat dengan cara yang baik dan benar. Ketiga, Kama ialah keinginan untuk mendapatkan kesukaan (kenikmatan), segala keinginan hendaknya dipenuhi, dilaksanakan dengan dasar kejujuran dan bertujuan untuk kesejahteraan, kesucian atau ketinggian masyarakat dijiwai dan didasarkan atas dharma ( Sudarta, 2001: 57).

Dalam hubungan ini ditegaskan bahwa, dharma memiliki posisi dan kedudukan yang paling penting dalam Triwarga, karena dharmalah yang mengantarkan seseorang mendapatkan kebahagiaan guna menuruti kama dalam menikmati artha di dunia ini. Apabila ketiga hal tersebut diperoleh dan bertumpu pada dharma atau kebenaran maka akan terciptalah kehidupan yang "Jagadhita"

Melalui pemahaman terhadap konsep yang telah diuraikan di atas, mengandung makna religius dan sarat dengan tuntunan moral dalam usaha menjaga nilai-nilai kemanusiaan, untuk membangkitkan kesadaran agar terpeliharanya kelangsungan ekosistem alam beserta isinya, demi terwujudnya keharmonisan dan keseimbangan hidup.

Hal tersebut sangat relevan dipakai sebagai dasar pemikiran untuk dijadikan konsep, yang nantinya dituangkan menjadi sebuah konteks pada suatu teks penciptaan karya seni lukis. Atas dasar pemahaman itu pula, maka distorsi/ penyimpangan sebagai suatu realitas kehidupan dan kepurbaan manusia, cenderung dilakukan dalam setiap usaha manusia untuk mencapai kemajuan material, oleh karena itu hal ini harus dikendalikan serta dikelola sebaikbaiknya melalui pencerahan maupun penyadaran dengan nilai-nilai moral yang selama ini terabaikan dan terlupakan.

Hidup menjadi berharga apabila setiap individu mengerti arti dari sebuah nilai, serta menyadari akan nilai-nilai yang ada pada dirinya sebagai makhluk sosial dan berbudaya, memiliki kemampuan cipta, rasa, dan karsa, seperti diuraikan oleh Sumardjo (2000: 147) sebagai berikut:

Bentuk-bentuk penilaian itu termuat dalam 4 lembaga kebenaran nilai, yakni sistem kepercayaan, sistem keilmuan, sistem filsafat, dan sistem kesenian. Seni adalah sebuah kosmos. Seni itu sebuah bentuk yang 
mengandung keteraturan dalam keutuhan dirinya. Seni, dengan demikian, juga mampu memberikan penilaian terhadap hidup yang chaos ini. Sen dapat memberi arti, memberikan harga terhadap hidup ini. Seni dapat membuat seseorang betah hidup di dunia karena memberikan pemahaman tentang arti hidup ini.

Begitu bernilainya suatu karya seni karena keteraturan dan keutuhan yang dimiliki, sehingga manusia dengan kemampuan cipta, rasa, dan karsanya, melalui karya seni mampu memberikan pemahaman, penilaian, penghargaan, serta arti terhadap kehidupan ini.

Pengamatan terhadap bentuk-bentuk rarajahan Bali sebagai salah satu bentuk karya sastra telah memberikan getaran intuitif yang mampu membangkitkan memori tentang nilai-nilai kehidupan sebagai suatu potensi atas munculnya dorongan baik internal maupun eksternal yang diekspresikan secara ekspresif ke dalam bahasa visual. Seni sebagai kegiatan rohani manusia diharapkan mampu membangkitkan pengalaman audiens, hal ini menurut $\mathrm{K}$. Mihardja dalam Soedarso (1990: 4), menyebutkan, "Seni adalah kegiatan rohani manusia yang merefleksi realitet (kenyataan) dalam suatu karya yang berkat bentuk dan isinya mempunyai daya untuk membangkitkan pengalaman tertentu dalam alam rohani si penerimanya. Dalam definisi ini dengan tegas dinyatakan, seni adalah kegiatan rohani, dan bukan semata-mata kegiatan jasmani.

Lewat media seni lukis, fenomena kehidupan akan diwujudkan melalui pemaknaan terhadap nilai-nilai distorsi dari bentuk-bentuk imajiner pada rarajahan Bali, sebagai esensi dari pengalaman indrawi yang terakumulasi dan terinkubasi dalam batin, kemudian dengan kemampuan teknik serta pertimbangan estetik yang dimiliki, akan diekspresikan secara kreatif sebagai representasi dari nilai-nilai kekinian. Hanya dengan tindakan kreatif, penghargaan terhadap sebuah nilai dapat diwujudkan ke dalam tataran visualisasi dari sebuah konsep, yang bersumber dari pengalaman estetik untuk diartikulasikan ke dalam bahasa rupa. Adapun yang dimaksud dengan "Nilai adalah semua yang dipandang berharga oleh orang atau kelompok orang serta dijadikan acuan tindakan maupun pengarti arah hidup. Nilai tersebut ditumbuhkan dan dibatinkan dalam kebudayaan orang itu, yang dihayati sebagai jagat makna hidup dan diwacanakan serta dihayati dalam bahasa jagat simbol" (Sutrisno, 2004: 197). Kata simbol (dalam bahasa Inggris symbol) mengandung arti: untuk sesuatu atau menggambarkan sesuatu, khususnya untuk menggambarkan sesuatu yang immaterial, abstrak, suatu idea, kualitas, tanda-tanda suatu obyek, proses dan lain-lain (Coulson dalam Titib, 2001: 63). Dalam hal ini penggunaan simbol pada suatu karya seni memiliki arti yang sangat penting karena tidak semua pengalaman manusia dapat dijabarkan secara verbal dan terinci, oleh sebab itu maka manusia menciptakan tanda, lambang, simbol sebagai media komunikasi.

Sehubungan dengan karya seni lukis yang diciptakan, pengalaman batin ditransformasikan ke dalam bahasa visual, sebagai suatu pencitraan terhadap nilainilai yang penuh makna, serta melalui distorsi dan aktualisasi tercipta karya seni yang bernuansa simbolik untuk menterjemahkan ide-ide yang bersumber dari bentuk-bentuk rarajahan Bali berkaitan dengan fenomena sosial yang terjadi saat ini. Dalam proses penciptaan karya seni lukis ini, elemen-elemen visual seperti: garis, bentuk, warna, tekstur, ruang, serta unsur-unsur pengorganisasiannya yang meliputi: komposisi, proporsi, kesatuan, keseimbangan dan lain sebagainya, memiliki peranan yang sangat penting sebagai standarisasi dalam menentukan kualitas suatu karya seni.

\section{Pengertian Garis}

Elemen garis dalam seni lukis adalah awal dari ekspresi dan ide dalam berkarya, dan garis juga dapat mereduksi seni pada bentuk yang paling sederhana. Garis sebagai bentuk mengandung arti lebih dari pada titik, karena dengan bentuknya sendiri garis menimbulkan kesan tertentu pada pengamat (Djelantik, 1999: 19).

Garis masih merupakan elemen yang penting dalam seni rupa, yang tidak terdiri dari bongkahan massa, melainkan massa dengan konturnya. Karena fundamentalnya suatu garis sehingga beberapa seniman tidak ragu lagi menganggapnya sebagai elemenpokok bagi semua seni rupa. Sebagaimana pernyataan Blake yang diungkap kembali oleh Read dalam Soedarso Sp. (2000: 20), antara lain: "pedoman yang penting dan ampuh bagi seni, juga buat kehidupan ini, adalah bahwa makin nyata, tajam, dan kuat garis batasnya, makin sempurna karya seni, dan kekurangjelasan serta kekurangtajaman pada garis besarnya merupakan bukti dari lemahnya imajinasi, peniruan dan kebodohan.

Dalam kaitannya dengan penciptaan ini pengalaman dan ide-ide diwujudkan dengan memanfaatkan kemampuan serta kekuatan garis positif dan negatif, dalam upaya menciptakan bentuk-bentuk yang representatif maupun bentuk abtraktif atau hanya semata-mata untuk memenuhi kebutuhan dalam pencapaian artistik.

\section{Pengertian Bentuk}

Dalam mendeskripsikan pengertian bentuk dalam suatu karya seni, elemen garis masih memiliki peranan yang dominan, baik terhadap karya seni dua dimensional maupun tiga dimensional. Pada karya dua dimensional garis berperan sebagai pembatas ruang, sedangkan pada karya tiga dimensional akan nampak garis imajiner apabila pusat perhatian diarahkan pada batas-batas mereka. 
Sehubungan dengan pengertian bentuk di atas, Burke dalam bukunya "Art As Image And Idea" atau "Seni Sebagai Ujud dan Gagasan" terjemahan Sp.

Gustami, (1991: 28-29), mengemukakan pengertian bentuk sebagai berikut: Bentuk adalah "manifestasi fisik luar dari suatu obyek yang hidup, tetap bidang adalah " manifestasi dari dari suatu obyek yang mati. Hasil berbagai bentukdapat memiliki kualitas linier jika perhatian kita diarahkan pada batas- batas mereka, tetapi kontur-kontur itu biasanya mempunyai efek membuat kita menyadari bentuk, yakni mereka menghadirkan warna-warna silhouette pada bidang atau ruang yang mereka pagari.

Dalam hal ini bentuk memiliki kualitas linier sebagai manifestasi fisik dari suatu obyek atau benda, sehingga mempunyai efek yang membuat kita menyadari adanya bentuk dan makna, dengan menghadirkan warna-warna silhouette pada bidang atau ruang yang dipagari. Di dalam memaknai suatu bentuk pada karya seni, Sumardjo (2000: 116) mengemukakan bahwa, bentuk seni inilah yang pertama-tama tertangkap oleh penikmat seni dan serta-merta dapa membangkitkan kepuasan atau kegembiraan. Dari nilai bentuk ini mulailah bangkit seluruh potensi diri penikmat untuk menggali lebih jauh nilai-nilai lain yang ditawarkannya. Dalam hubungan ini bentuk karya yang diciptakan diwujudkan ke dalam bentuk-bentuk yang representatif dan abtraktif antara lain figur-figur manusia, benda budaya, serta bentuk-bentuk non konvensional yang dapat menghadirkan pencitraan bentuk-bentuk imajinatif yang mewakili konsep distorsi bentuk pada karya seni lukis yang diciptakan.

\section{Pengertian Warna}

Warna sebagai salah satu elemen visual dalam seni lukis digunakan untuk sampai kepada kesesuaian dan kenyataan, sebagaimana pada pelukis-pelukis realis atau naturalis. Namun warna juga digunakan tidak demi bentuk, tetapi demi warna itu sendiri, dan untuk mengungkapkan kemungkinan-kemungkinan keindahannya serta dapat digunakan untuk berbagai pengekspresian (Sidik dan Prayitno, 1979

8). Fungsi warna dalam hal ini adalah sebagai sarana pencapaian estetik pada suatu karya terutama menyangkut keindahan-keindahan yang akan diwujudkan sesuai dengan keindahan bentuk yang diinginkan, serta merupakan media ekspresi dan individual sifatnya. Pilihan terhadap warna tertentu bagi seorang seniman terkadang menghadirkan keunikan tersendiri pada hasil karya ciptanya, serta melalui citarasa warna tertentu juga akan tercermin karakter dan suasana hat seseorang, sehingga bagi sebagian orang warna memiliki arti dan perlambang tertentu dalam kehidupannya.
Warna-warna yang ditampilkan untuk mendukung dan mewakili tema maupun konsep distorsi bentuk pada karya cipta ini, adalah warna imajiner yang memiliki kandungan makna dan filosofis tertentu dalam suatu penafsiran, sebagai media dalam pengungkapan ekspresi ide-ide, kemudian disusun bervariatif tanpa mengabaikan keharmonisannya.

\section{Pengertian Tekstur}

Tekstur adalah nilai raba pada suatu permukaan, baik itu nyata maupun semu. Suatu permukaan mungkin kasar, mungkin halus, keras atau lunak dan licin. Pada tekstur nyata apabila permukaannya diraba akan nampak kasar secara nyata, sedangkan pada tekstur semu, permukaan nampak seolah-olah kasar namun ketika diraba halus. Tekstur memiliki kualitas plastis sehingga muncul bayang-bayang pada permukaannya, dan karena kualitas plastis yang dimilikinya itu, tekstur dikatakan memliki nilai dekoratif yang tinggi (Sidik dan Prayitno, 1979: 26)

Tampilan tekstur pada kaya-karya yang diciptakan didominasi oleh tekstur nyata atau kasar, oleh karena tekstur tersebut mempunyai kualitas plastis dan nilai dekoratif yang tinggi, dalam hal ini penerapannya diharapkan dapat mewujudkan bentuk dan pencapaian artistik pada seni lukis yang diciptakan.

\section{Konsep Perwujudan}

Dalam mewujudkan konsep distorsi bentuk yang bersumber dari bentukbentuk rerajahan ke dalam karya seni lukis, aspek bentuk divisualisasikan dengan menampilkan bentuk-bentuk yang representatif, serta bentuk-bentuk abstraktif sebagai simbol dua kekuatan besar yang berbeda antara yang konstruktif dengan distorsif/dekonstruktif, antara kekuatan dunia materi dengan spiritual yang keduanya saling membutuhkan. Bentuk-bentuk reprewsentatif yang dimaksud dalam penciptaan ini adalah bentuk yang diciptakan dapat mewakili suatu penafsiran, namun keberadaannya masih dapat dilacak atau dibaca sumber bentuknya, sedangkan bentuk-bentuk abtraktif adalah bentuk-bentuk non konvensional yang diwujudkan berdasarkan kemampuan imajinatif. Kemudian secara konsepsional di dalam suatu perwujudan karya seni dapat mengkhadirkan unsur-unsur distorsi bentuk yang mencerminkan tentang kehidupan yaitu menyangkut nilai-nilai filosifis berinspirasikan bentuk-bentuk rarajahan Bali.

Secara teknik, visualisasi karya diwujudkan dengan memanfaatkan elemen-elemen visual seni rupa beserta prinsip-prinsip penyusunannya yang meliputi: garis, bentuk, warna, tekstur, bidang atau ruang, irama. Adapun terjemahan garis yang diaplikasikan pada karya lukis yang diciptakan, merupakan kombinasi penerapan garis positif dan negatif. Garis positif dicapai melalui goresan kuas atau menggunakan pisau palet, sedangkan pada garis negatif pencapaiannya diperoleh melalui batas limit suatu bentuk atau warna yang 
meliputi; garis lurus panjang dan pendek, lengkung, meliuk-liuk, garis spontan yang disusun/ditata sedemikian rupa menjadi satu keutuhan yang harmoni.

Bentuk-bentuk representatif dan bentuk-bentuk abstraktif pada karya tersebut diwujudkan melalui susunan garis, warna dan tekstur yang dibentuk dan disusun sedemikian rupa, namun tetap berpedoman pada pertimbanganpertimbangan yang menyangkut: proporsi, komposisi, irama, ruang, pencapaian volume/gelap-terang serta keseimbangan (balancing) sehingga bentuk yang diciptakan dapat mewakili pencitraan terhadap tema atau konsep distorsi bentuk yang dimaksudkan.

Warna-warna imajiner yang bermakna simbolik diterapkan, merupakan hasil pengolahan melalui pencampuran antara warna primer dengan sekunder yang disesuaikan dengan kebutuhan ekspresi. Tekstur nyata atau kasar yang diaplikasikan pada karya tersebut dicapai dengan cara memberikan aksentuasi goresan kuas dan warna atau dengan goresan warna yang spontan dengan menggunakan pisau pallet.

Penggunaan ruang padat pada karya yang diciptakan sangat dominan, sedangkan pemanfaatan ruang kosong diharapkan agar dapat mencapai imajinasi keruangan, sehingga objek-objeknya yang padat memenuhi suatu komposisi tata ruang memberikan impresi visualisasi karya dengan karakter yang cenderung dekoratif. Dalam karya seni lukis, irama merupakan aspek yang sangat prinsipal, karena dengan pemanfaatan irama yang variatif akan dapat menambah karakteristik karya yang dinamis agar suasana yang dimunculkan nampak lebih menyenangkan atau menggembirakan. Pada karya cipta ini, irama ditampilkan melalui komposisi irama garis/goresan warna yang variatif, demikian juga tataletak penyusunannya yang dinamis, sehingga kesan monotone yang cenderung menyebabkan kembosanan dalam pengamatan dapat diminimalisasi, tentunya upaya seperti ini disesuaikan dengan gagasan yang akan diwujudkan.

\section{METODE/ PROSES PENCIPTAAN}

\section{Metode Penciptaan}

Dalam proses penciptaan karya seni lukis ini, diperlukan suatu metode untuk menguraikan secara rinci tahapan-tahapan yang di lakukan dalam proses penciptaan, sebagai upaya dalam mewujudkan karya seni. Melalui pendekatanpendekatan dengan disiplin ilmu lain, dimaksudkan agar selama dalam proses penciptaan dapat dijabarkan secara ilmiah dan argumentatif. Dalam kaitannya dengan metode pendekatan tersebut sehubungan dengan karya yang diciptakan, Sachari (2000:223), bahwa selama ini penelitian yang bersifat proses penciptaan dengan bahasa rupa dapat dikelompokkan dalam dua katagori, yaitu kajian estetik dan proses desain. Dalam kajian estetik jurus-jurus yang sering dipakai oleh seniman dan perancang dalam penggalian ide dapat dilakukan dengan beberapa pendekatan: a) heurostik: spontanitas dan kreatif; b) semantik: metafor atau kepatutan; c) sinektik: analogi atau fantasi; d) semiotik: pengkodean atau penandaan; e) simbolik: pemaknaan atau penyimbolan; f) holistik: bersifat universal dan global; g) tematik: pendekatan tema tertentu; h) hermeneutik: tafsiran atau interpretasi.

Mengacu pada pendapat di atas, maka dalam proses penciptaan karya seni lukis ini menggunakan metode pendekatan semiotik, karena data-data yang akan dicermati dalam penciptaan ini berupa tanda-tanda. Sedangkan metode pendekatan hermeneutik dan simbolik digunakan karena data-data yang akan dicermati berupa interpretasi, dan berupa simbol-simbol. Demikian juga halnya menyangkut metode penciptaan yang digunakan dalam penciptaan ini adalah menggunakan teori Hawkins. Teori ini diaplikasikan karena metode tersebut dapat dipakai sebagai rambu-rambu yang menuntun dan mengarahkan pola pikir dan pola tindak untuk lebih sistimatis dalam mengimplementasikan ide-ide dan tahapan penciptaan, sehingga persoalan-persoalan yang dihadapi dalam proses penciptaan ini dapat dideskripsikan dan dielaborasi secara optimal.

Hawkins dalam bukunya Creating Through Dance yang diterjemahkan oleh RM. Soedarsono (2001: 207), menjelaskan bahwa: penciptaan seni lukis dan seni tari yang baik, selalu melewati tiga tahap: pertama exploration (eksplorasi); kedua improvisation (improvisasi); dan yang ketiga forming (pembentukan atau komposisi). Dengan tidak mengurangi intisari dari apa yang diajukan oleh Hawkins dalam Hadi (2003: 24,29,40) menterjemahkan, metode tersebut meliputi: eksplorasi, improvisasi, dan forming (pembentukan). Eksplorasi yang dimaksud dalam hal ini adalah sebagai langkah awal dari suatu penciptaan karya seni. Tahap ini termasuk berpikir, berimajinasi, merasakan dan merspon objek yang dijadikan sumber penciptaan; Improvisasi tahap ini memberikan kesempatan yang lebih besar bagi imajinasi, seleksi dan mencipta dari pada tahap eksplorasi. Karena dalam tahap improvisasi terdapat kebebasan yang baik, sehingga jumlah keterlibatan diri dapat ditingkatkan. Dalam tahap improvisasi memungkinkan untuk melakukan berbagai macam percobaan-percobaan (eksperimen) dengan berbagai seleksi material dan penemuan bentuk-bentuk artistik, untuk mencapai integritas dari hasil percobaan yang telah dilakukan. Forming (pembentukan), tahap ini adalah suatu proses perwujudan (eksekusi) dari berbagai percobaan yang telah dilakukan. Kebutuhan membuat komposisi tumbuh dari hasrat manusia untuk memberi bentuk terhadap sesuatu yang telah ditemukan. Tahap ini merupakan proses penyusunan dengan menggabungkan simbol-simbol yang dihasilkan dari berbagai percobaan yang berdasar pada pertimbangan harmoni, kerumitan, intensitas dan lain sebagainya.

Dalam kaitannya dengan proses perwujudan menurut Djelantik (1990: 57), terjadi dalam dua tahap: (a) penciptaannya yang mulai dengan dorongan yang 
dirasakan, disusul "ilham", yang menemukan cara-cara untuk perwujudan, (b) pekerjaan membuat karya itu sendiri sampai selesai. Hasilnya disebut "kreasi" atau "ciptaan". Dengan demikian dalam proses perwujudan karya ini digunakan metode tersebut di atas melalui langkah-langkah sebagai berkut.

\section{Tahap Eksplorasi}

Pada tahapan awal proses penciptaan seni lukis ini, yaitu melakukan pengamatan dan pencermatan terhadap bentuk dan nilai-nilai simbolik pada rarajahan Bali, yang di dalamnya terkandung ajaran-ajaran spiritual tentang ilmu gaib yang dualistik, untuk dijadikan sumber inspirasi. Pengamatan terhadap rarajahan tersebut dilakukan dengan cara mengamati ke museum-museum purbakala, seperti; museum Gedong Kertya di Singaraja, dan Museum Bali yang menyimpan buku-buku rarajahan Bali, serta lontar bergambar yang memiliki nila magis baik untuk pengobatan atau untuk menyakiti/mencelakakan orang. Di samping itu ada pula bentuk-bentuk rarajahan yang memiliki fungsi untuk memperoleh kekuatan/kekebalan dan perlindungan/penolak bala dari kekuatan mistik. Dalam penelitian ini juga dilakukan pengkajian dengan membaca referensi buku-buku tentang cara pengobatan tradisional Bali seperti: usada edan/ usada buduh (pengobatan untuk orang yang terkena penyakit jiwa/gila), usada tumbal (untuk penjaga rumah/pekarangan), usada tatenger beling (untuk pengobatan orang yang sedang hamil), Usada Tiwas Punggung (untuk pengobatan badan/phisik manusia secara keseluruhan).

Melalui pengamatan dan seleksivitas terhadap hasil eksplorasi serta bersumber dari pengalaman-pengalaman pribadi masa lalu, telah mengusik ruang imajinasi, sehingga muncul kegelisahan-kegelisahan yang obsesif, untuk menghadirkan bentuk-bentuk imajinatif yang representatif dengan konsep baik secara teks maupun konteksnya.Yang tidak kalah pentingnya adalah melakukan wawancara dengan orang-orang yang dianggap kompeten dalam bidang in seperti; balian/dukun, pemangku (orang yang biasanya sering memimpin pelaksanaan upacara di lingkungan masyarakat Bali), pendeta dan sastrawan tradisional Bali, sebagai bahan kajian untuk memperoleh data primer untuk mendukung serta melengkapi akurasi data yang ada.

\section{Tahap Eksperimentasi}

Dalam melakukan eksperimentasi, ada lima komponen kreativitas produksi dari gagasan baru yang bernilai yang ditawarkan oleh Sternberg dan Lubant dalam Myers, (2004: 102-104), yang meliputi: komponen pertama adalah keahlian. Semakin banyak gagasan dan citra yang kita peroleh melalui pembelajaran yang terakumulasi, semakin banyak banyak kesempatan yang kita miliki untuk mengombinasikan blok-blok bangunan dengan cara kreatif.
Komponen kedua adalah keterampilan-keterampilan berpikir imajinatif. Dalam momen-momen kreativitas, kita melihat segala hal dengan cara-cara baru, mengenali pelbagai pola dan menciptakan pelbagai hubungan. Setelah menguasai anasir-anasir mendasar dari sebuah persoalan, kita mendefinisikan ulang atau mengeksplorasinya dengan cara baru. Komponen ketiga adalah kepribadian yang senang bertualang. Pribadi yang kreatif mampu menanggung ketaksaan (ambiguity) dan risiko, gigih dalam mengatasi pelbagai rintangan, dan berusaha mencari pengalaman baru. Komponen keempat adalah motivasi intrinsik. Masyarakat akan menjadi lebih kreatif ketika mereka merasa termotivasi terutama oleh kepentingan, kesenangan, kepuasan dan tantangan dari kerja itu sendiri alihalih oleh pelbagai tekanan dari luar. Komponen yang kelima adalah lingkungan yang kreatif. Gagasan-gagasan yang baru dan bernilai sering kali dicetuskan, didukung dan disaring oleh banyaknya hubungan.

Kelima gagasan di atas telah memberikan dorongan dan rangsangan batin untuk menumpahkan segala kegelisahan diri melalui media eksperimentasi atau percobaan-percobaan dengan membuat setsa-sketsa kreatif dan improvisatif dari bahan kertas, tinta cina dan pensil, dengan maksud agar pengalaman-pengalaman masa lalu yang telah terekam dalam memori, terstimulasi kembali untuk menggali potensi imajinasi yang ada, sehingga diharapkan dapat melahirkan motif-motif serta ide-ide yang cemerlang. Sketsa-sketsa tersebut sebelumnya diseleksi kemudian beberapa dipilih untuk direkonstruksi, serta dielaborasi karena telah sesuai dengan rancangan yang akan diwujudkan dan dipakai sebagai acuan dalam proses penciptaan karya seni lukis. Sketsa-sketsa yang terpilih tidak mutlak ditransfer langsung untuk diwujudkan ke dalam karya, melainkan melalui pertimbangan-pertimbangan menyangkut ide, estetik, dan artistik, sketsa-sketsa tersebut ditinjau serta diseleksi kembali bahkan adakalanya tidak terpakai sama sekali, karena dianggap gagal sebagai suatu rancangan serta tidak sesuai dengan gagasan yang diinginkan. Di samping itu pembuatan sketsa dapat dilakukan secara langsung dan improvisatif dengan menggoreskan ujung tangkai kuas yang diruncingkan pada permukaan kanvas ketika bahan tekstur telah ditempelkan secara merata. Melalui pengalaman intuitif yang terinkubasi dalam memori serta didorong oleh getaran emosi, melahirkan motif serta figur-figur imajinatif dan representatif, sesuai dengan ide-ide yang ada korelasinya dengan konsep, untuk diekspresikan ke dalam karya seni lukis. Langkah kedua dari proses rancangan ini juga dilakukan dengan merekonstruksi/ mengkombinasikan sketsa-sketsa yang terpilih untuk dijadikan rancangan karya seni lukis yang nantinya dapat dipakai sebagai pedoman dalam merealisasikan suatu gagasan penciptaan. 
Gambar 2 Sketsa-sketsa hasil eksperimentasi. Bahan: pensil pada kertas

\section{Tahap Pembentukan}

Tahap pembentukan merupakan proses transformasi bentuk yan bersumber dari sketsa-sketsa terpilih, kemudian direkonstruksi dan dielaboras pada bidang kanvas. Dalam proses tersebut terkadang mengalami perkembangan dan perubahan pemikiran yang signifikan terhadap rancangan sketsa sebelumnya, karena dalam proses kreatif akan setalu melibatkan intuisi untuk melakukan terobosan-terobosan baru terhadap berbagai aspek sehingga hal-hal yang menyangkut pengolahan komposisi, pewarnaan, aplikasi tekstur, pembagian ruang dan lain-lain, selalu disesuaikan berdasar atas kebutuhan ekspresi, estetik, sert artistik yang merupakan bagian darígagasan yang akan diwujudkan.

Adakalanya proses pembentukan dilakukan melalui goresan warnawarna yang improvisatif dan variatif pada kanvas yang telah ditekstur secara merata. Dengan menerapkan dan menyusun anasir-anasir kekuatan garis yang dimiliki, serta memanfaatkan kemampuan teknik pewarnaan yang tumpang tindih (impasto), maka bentuk atau figur-figur yang ditampilkan mampu menghadirkan asosiasi tematis dan mendukung gagasan yang diharapkan.

Di samping itu, munculnya image bentuk, figur, serta motif-motif pada tahapan pembentukan ini, juga dapat dicapai dengan menggunakan bahan tekstur berupa modeling paste yang dirol atau digoreskan menggunakan pisau palet dengan ketebalan yang optimal sesuai dengan bentuk yang ingin dicapai. Tekstur tadi kemudian digores-gores dengan tangkai kuas yang runcing sehingga akan muncul jejak-jejak garis atau goresan-goresan yang artistik ketika jejak garis da goresan tersebut diberi warna gelap sehingga dalam proses pewarnaan selanjutnya dapat dicapai warna yang imajiner, padat, dan variatif yang dapat mewakili nilainilai simbolik yang diinginkan. Kiat-kiat semacam ini dilakukan dengan harapan agar efek-efek tersebut dapat menunjang kualitas estetik serta artistik pada karya, dan mampu membangkitkan impresi kedalaman, kesan magis, melalui nilai-nilai simbolik yang ditampilkan. Adapun material cat yang digunakan adalah cat akrilik, karena material ini memberikan kemudahan-kemudahan yang berarti, dalam mencapai efektifitas dan efisiensi kerja, serta memiliki sifat menutup yang kuat dan mudah kering sehingga teknik impasto dapat diaplikasikan dengan sempurna untuk mencapai keaslian karya seni lukis (authenticity of the art work).

Pada tahap pembentukan, diperlukan seperangkat piranti berupa alat dan bahan dalam mewujudkan gagasan-gagasan ke dalam karya seni lukis. Adapun bahan yang dipakai adalah berupa: kanvas, cat akrilik, bahan tekstur berupa modeling paste, dan air sebagai pencair warna. Sedangkan alat-alat yang dipergunakan adalah: pisau pallet, kuas dengan berbagai jenis ukuran, alat rol, serta lempengan kaca sebagai tempat mencampurkan cat. Setelah bahan dan alat tersedia, tahapan-tahapan yang harus dilalui dalam proses pembentukan ini dapat diuraikan sebagai berikut.

Pertama, menempelkan modeling paste yang digunakan sebagai tekstur pada permukaan kanvas secara merata dengan menggunakan roller atau pisau pallet, agar efek tekstur yang akan diharapkan tampak nyata dan terkesan tebal. Tekstur-tektur tadi kemudian dapat dibentuk untuk menciptakan motif maupun figur-figur yang diinginkan sesuai dengan kebutuhan ekspresi, serta bentuk estetik yang diinginkan. Tanpa harus berlama-lama menunggu keringnya tekstur tadi, elaborasi tekstur yang telah terbentuk sudah dapat digoreskan atau diblok dengan warna dasar gelap seperti: warna hitam, coklat, biru tua atau warna gelap sejenisnya. Hal ini dimaksudkan agar efek nuansa warna gelap pada tekstur, muncul lebih artistik apabila pada permukaan kanvas dipolesi dengan intensitas warna terang atau warna yang lebih muda. Warna-warna terang tadi digoreskan dengan posisi kuas mengambang, spontan dan impresif pada permukaan kanvas, diharapkan dapat memuncukan efek tekstur yang terkesan empuk, unik dan artistik serta berperan untuk memberikan aksentuasi pada objek atau motif yang ingin ditonjolkan. Penerapan warna-warna dan garis yang bervariatif dilakukan secara bertahap dan berulang-ulang terutama untuk mencapai bentuk-bentuk yang elaborit dan warna-warna yang padat, demikian juga pada bentuk-bentuk utama yang ingin ditonjolkan untuk tampil sebagai pusat perhatian. Pada tahapan proses finishing nanti, diupayakan adanya kontrol yang cermat, teliti dan menyeluruh sehingga bagian-bagian yang belum tergarap segara maksimal dapat disempurnakan kembali melalui goresan-goresan yang lembut, ekstra teliti serta penuh kesabaran karena hal ini akan menentukan aksentuasi pada tahap proses penyelesaian karya, sehingga ide-ide yang dituangkan ke dalam karya seni lukis 
dapat diartikulasikan dengan sempurna.

Kedua, karya seni lukis yang telah selesai dikerjakan, divernish dengan acrylik vernis matt, agar kekuatan material/bahan dapat terjaga dan terpelihara dengan baik sehingga karya-karya menjadi lebih awet dan tahan lama, terhindar dari kotoran debu ataupun jamur sehingga tampilan warna-warnanya tampak cemerlang dan tidak mengkilat. Untuk menjaga perfeksi penampilan, karya-karya yang telah selesai dilengkapi frame atau bingkai yang merupakan standarisai dari penciptaan seni lukis ini, dengan tetap mempertimbangkan keharmonisan karya yang berkaitan dengan; pemilihan jenis motif atau model frame yang dipakai, serta penggunaan warna disesuaikan dengan warna-warna yang ada pada karya lukisan. Dengan demikian, melalui beberapa proses dan berbagai tahapan serta pertimbangan-pertimbangan yang mantap, maka dapat diyakini bahwa karya-karya yang telah selesai dikerjakan sudah layak untuk dipamerkan ke medan sosial yang lebih luas untuk dinikmati dan diapresiasi oleh khalayak ramai, sebagai salah satu bagian dari tanggung jawab moral seniman dalam meningkatkan apresiasi seni dan budaya masyarakat.

\section{Ulasan Karya}

Penciptaan seni lukis dilakukan melalui beberapa tahapan yang sangat mendasar dan merupakan sebagian dari proses kreatif termasuk kendala dan resiko yang dihadapinya serta akan menentukan arah dan perjalanan keseniannya di dalam pencarian jatidiri maupun eksistensi keseniannya. Bilamana seorang pencipta telah berhasil dalam memvisualisasikan ide-idenya dengan segala totalitasnya, saat itu pula ia telah mencurahkan luapan emosinya secara kreatif ke dalam bahasa visual yang diwujudkan berupa karya seni lukis.

Kreatifitas seorang seniman merupakan aktualisasi diri yang diekspresikan dalam bentuk gagasan-gagasan baru, yang muncul akibat dar berbagai stimulan, baik subjektif maupun objektif yang mengantarkan keliarankeliaran imajinasinya menuju ke pengembaraan estetik secara mendalam kemudian diabstraksikan sehingga melahirkan simbol-simbol yang individual.

Motivasi diri yang bermuara pada pencapaian legitimasi eksistensi sebagai pelukis tidak hanya didasarkan atas karya-karya seni dalam tataran tekstual atau estetik semata, melainkan juga tataran kontektualnya yaitu secara intrinsik menyangkut tentang bagaimana karya seni itu diciptakan serta makna apa yang terkandung di balik pencitraan dari simbol-simbol tersebut. Selebihnya adalah bagaimana mewacanakannya ke medan sosial yang lebih luas sebagai salah satu kontribusi pemikiran dalam meningkatkan wacana dan apresiasi seni masyarakat.

Konsep penciptaan yang melandasi karya-karya yang dipamerkan saat ini, idenya bersumber dari pemaknaan terhadap fenomena kehidupan yang terjadi di lingkungan masyarakat dewasa ini. Segala kepentingan yang berorientasi pada kebutuhan materi yang berlebihan, didukung oleh pola pikir dan pola tindak yang individual serta mengabaikan nilai-nilai moral dan prinsip/konsep keseimbangan, menyebabkan terjadinya berbagai kerawanan baik di bidang sosial dan budaya, ekonomi maupun politik.

Persoalan di atas apabila tidak diantisipasi secara dini dan penuh kearifan, hal ini cenderung akan melahirkan konflik horisontal, munculnya tindakan-tindakan anarkis yang menyebabkan kerusakan lingkungan, pemaksaan kehendak, pelecehan harkat dan martabat manusia akibat pelanggaran HAM, serta penyimpangan-penyimpangan di bidang keuangan dan administrasi negara yang menyebabkan terjadinya korupsi di mana-mana.

Dalam konteks ini Rarajahan bagi masyarakat Bali mengandung dua nilai yang berbeda disebut dengan "Rwabhineda", diyakini sebagai tuntunan spiritual yang memberikan pencerahan dalam kehidupan sehari-hari, berorientasi pada keseimbangan hidup baik lahir maupun batin. Pemahaman terhadap nilai-nilai tersebut di atas memberikan getaran serta dorongan emosional, sehingga terprovokasi untuk dijadikan sumber inspirasi, kemudian diaktualisasikan ke dalam karya seni lukis berupa simbol-simbol dengan menawarkan ide-ide tentang konsep keseimbangan, yang dewasa ini sudah terabaikan bahkan ditinggalkan

Agar artikulasi karya yang diciptakan dapat dipahami baik dari segi teks maupun konteksnya, atau visual maupun ide dan konsep-konsepnya, serta dalam memudahkan terjadinya kontak/komunikasi antara karya seni dengan apresian, antara seniman dengan apresiator, di bawah ini akan diuraikan secara rinci mengenai ulasan masing-masing karya-karya sebagai berikut.

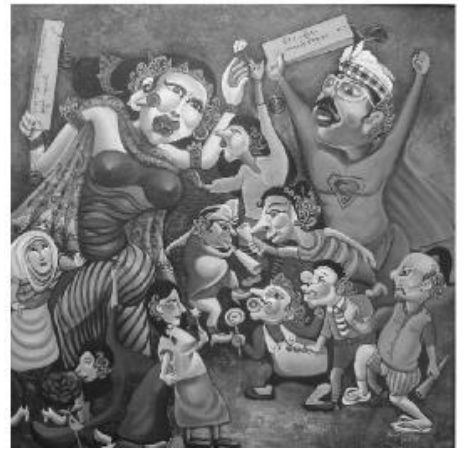

Gambar 3 (karya 1) Cinta kasih Dewi, 2007 Akrilik pada kanvas, 90 cm x $90 \mathrm{~cm}$

Kehidupan dualistis (laki dan perempuan, baik dan buruk, hidup dan mati), adalah merupakan suatu kenyataan yang harus dilalui dan dihadapi dengan penuh kesadaran diri, sehingga dapat menerima segala sesuatunya serta perbedaan 
yang ada dilingkungan kita sebagai suatu keindahan serta karunia Tuhan. Kenyataa-kenyataan tersebut di atas secara visual digambarkan dengan sosok/ figur seorang Ibu (Ibu Pertiwi sebagai simbol kekuatan dunia materiel) sedang membawa sehelai daun lontar yang bertuliskan "Ing Madia Mangun Karsa, Ing Ngarso Sung Tulodo, Tut Wuri Handayani”. Secara filosofis ini diartikan bahwa, seorang Ibu hendaknya memberikan tuntunan dan pengayoman bagi perkembangan anak-anak bangsa tanpa harus membedakan keberadaannya, agar kelak nanti bisa tumbuh menjadi anak-anak bangsa yang mandiri dan menjunjung tinggi nilai-nilai perbedaan dan cinta kasih.

Sedangkan sosok/figur Bapak (sebagi simbol Akasa/dunia spiritual) yang digambarkan membawa sehelai daun lontar bertuliskan "Sepi ing Pamrih Rame Ing Gawe", dalam hal ini seorang Bapak harus bekerja keras tanpa mengharapkan hasil dari karya-karyanya itu, artinya disamping mengayomi anak-anak bangsa secara materiel juga mengarahkan jiwanya menuju kehidupan berakhlak dan berbudi pekerti yang baik untuk menuju kehidupan serasi selaras dan seimbang lahir maupun batin.

Figur anak-anak yang sedang bermain dalam merayakan hari kemenangannya digambarkan secara dinamis mengelilingi Bapak dan Ibu, sebagai simbol akan keanekaragaman anak-anak bangsa yang selalu membutuhkan cinta dan kasih sayang dari seorang Ibu dan Bapak dalam melakukan interaksi sosial diantara sesama. Narasi karya di atas dikombinasikan dengan perpaduan garis, warna tekstur dan komposisi ruang yang dinamis, sebagai simbol dinamika kehidupan beragam yang menjunjung tinggi nilai-nilai toleransi hidup kebersamaan.

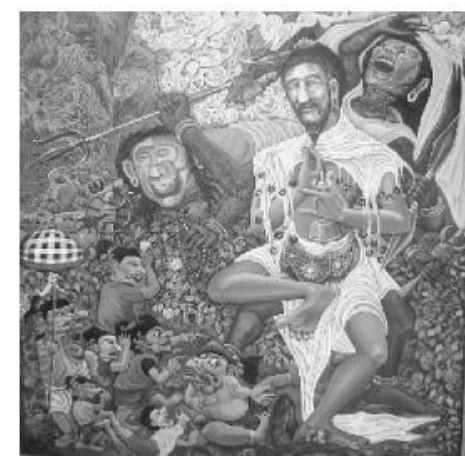

Gambar: 4 (karya 2) Dualisme Kehidupan, 2007 Akrilik pada kanvas 90 cm x 90 cm

Kehidupan yang dualistis ini apabila tidak disikapi dengan pikiran yang arif sunguh sangat membahayakan tatanan yang ada. Masing-masing kelompok akan mengklaim bahwa dirinya yang paling benar, paling kuat, paling berani, sehingga sifat dan arogansi semacam inilah akan menimbulkan konflik perpecahan dalam suatu tatanan kehidupan yang beraneka ragam. Hal tersebut digambarkan dengan sosok/figur manusia wayang sebagai simbol serta mencerminkan kehidupan saat ini yang cenderung menggunakan kekuatankekuatan pisik untuk menekan kaum yang lemah dalam mencapai suatu tujuan. Di tengah-tengah sosok manusia wayang digambarkan sosok/figur seorang pendeta berdiri, dengan di bayang-bayangi mahluk gaib dengan segala kekuatan dan senjata ditangannya, sambil melantunkan mantra-mantra dan doa demi terciptanya perdamaian dunia, karena selalu dibayang-bayangi oleh rasa keprihatinan yang mendalam akan terjadinya perang yang terus berkecamuk di berbagai belahan dunia. Sedangkan pada bagian atas dari narasi karya ini digambarkan asap yang mengepul dengan warna putih keabuan, air laut yang meluap dengan warna biru, sebagai simbol hasil akibat perbuatan manusia yang sedang bertikai dengan menggunakan kekuatan-kekuatan konvensional bahkan inkonvensional yang dapat mengancam seluruh kehidupan dunia.

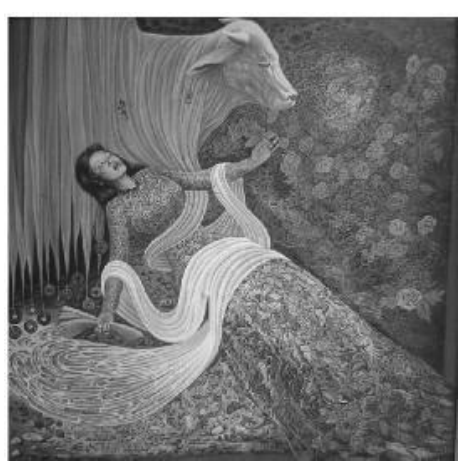

Gambar: 5 (karya 3) Ketaksaan, 2007 Akrilik pada kanvas, 90 cm x 90 cm

Dalam kehidupan yang dualistis ini manusia sering dibuat tak berdaya karena harus dihadapkan pada dua pilihan berbeda, menyebabkan antara yang baik maupun buruk sering tidak jelas definisi dan batasannya, sehingga susah ditemukan ujung pangkal dari jawaban itu. Demikian juga pada diri manusia yang ambigu ini, sering menjadi susah kemudian sakit dan akhirnya mati, ketika harus menentukan satu di antara dua pilihan yaitu antara cinta dan kesadaran/kedamaian. Dalam visualisasi karya digambarkan figur wanita menggenggam lontar/pustaka suci pada tangan kanan simbol kesadaran/kedamaian sebagai kekuatan spiritual (sebagaimana sifat-sifat Dewa) untuk mencapai kelepasan, sedangkan tangan kirinya memegang sekuntun bunga mawar merah sebagai simbol cinta yang mendalam tehadap materi/kekuatan duniawi (sebagaimana sifat-sifat Bhuta), dan terkadang mengantarkan hidup manusia ke lembah nista, akhirnya menuju 
kehancuran. Figur sapi digambarkan pada kulitnya berikatkan uang kepeng, namun di bagian lain, kulit yang menyerupai kain dengan motif ekor burung merak melilit pada bagian tubuh wanita sebagai simbol kekuatan Ibu Pertiwi/dunia materi sedang meliput/mendominasi jiwa anak manusia. Makna yang dapat dipetik dari narasi karya lukis ini adalah bahwa dalam kehidupan yang dualistis ini, antara kebutuhan duniawi/materiel dengan kebutuhan spiritual hendaknya selalu hidup berdampingan, serasi selaras dan seimbang sehingga dalam kehidupan ini maupun nanti dapat dicapai jalan menuju kelepasan (terbebas dari segala siksaan) baik dunia maupun akhirat.

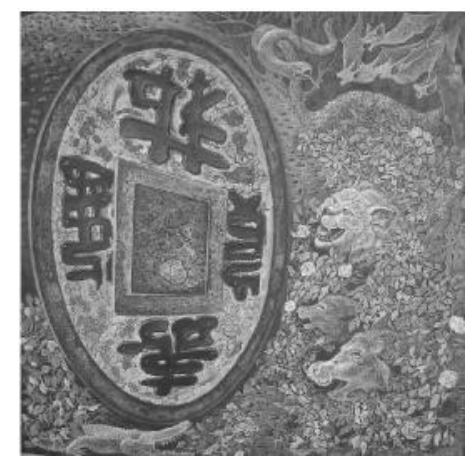

Gambar: 6 (karya 4) Alam Menggugat, 200. Akrilik pada kanvas, $140 \mathrm{~cm}$ x $140 \mathrm{~cm}$

Akibat sifat rakus dan berkuasa dari manusia dalam memanfaatkan sumber daya alam, mengakibatkan terjadinya kerusakan lingkungan di mana-mana. Bumi, air dan gas alam, baginya adalah potensi yang harus dimanfaatkan untuk kepentingan ekonomi, dikelola dan eksploitasi secara berlebihan tanpa memikirkan nasib generasi yang akan datang. Yang lebih parah lagi adalah terjadinya kerusakan hutan di berbagai belahan dunia akibat illegal logging sehingga muncul isu baru tentang pemanasan global (global warming) yang meresahkan masyarakat dunia internasional. Ini membuktikan bahwa alam yang dieksploitasi secara berlebihan tanpa memikirkan keasrian serta kelestariannya akan berbalik menggugat umat manusia melalui sifat-sifatnya yang alamiah berupa terjadinya suatu musibah, malapetaka dan bencana yang dapat mengancam bahkan menelan korban manusia dan harta benda. Gagasan tersebut pada visualisasi karya digambarkan lahan hutan yang sudah rusak akibat ulah manusia, sehingga penghuni hutanpun nampak hidup secara liar dan kelaparan, yang pada akhirnya kehidupan ini menjadi semakin tidak tertata lagi dengan baik (chaos). Sedangkan bentuk uang kepeng yang digambarkan menyatu dengan bentuk/motif batu adalah sebagai simbol bahwa, segala sesuatu yang ada dan dapat dimanfaatkan semata-mata diukur dengan kekuatan materi, namun pada akhirnya bermuara pada tindakan kekerasan dengan mengkambinghitamkan masyarakat bawah.Warna-warna pada visualisasi karya ditampilkan dengan dominasi/ kombinasi warna coklat untuk mencapai impresi gersang pada suasana hutan yang telah rusak, serta aksentuasi warna biru sebagai representasi dari anak sungai yang mati akibat pencemaran limbah.

\section{SIMPULAN}

Distorsi bentuk yang bersumber dari bentuk-bentuk Rarajahan Bali adalah mencerminkan dua kekuatan besar yaitu antara yang konstruktif dengan distorsif selalu menjiwai kehidupan ini. Oleh karena itu bagi masyarakat Bali hal ini diyakini sebagai dua unsur kekuatan yang selalu ada, saling tarik-menarik serta saling melengkapi. Konsepsi dualistis dalam masyarakat Hindu di Bali, serta tertuang dalam pustaka-pustaka suci (lontar), buku-buku Rarajahan yang berisikan tentang berbagai hal yang berhubungan dengan kehidupan yang meliputi; dunia spiritual, magis/mistik, demikian juga menyangkut cara pengobatan tradisional Bali, menjadi bagian yang penting dan tak terpisahkan dalam tatanan kehidupan socio-cultural masyarakat Bali. Dalam mengimplementasikan konsep serta nilainilai di atas, selalu berorientasi pada prinsip-prinsip keseimbangan hidup demi terciptanya kehidupan yang Jagadhita.

Distorsi bentuk sebagai sebuah konsep penciptaan seni lukis, merupakan pemaknaan terhadap nilai-nilai Rarajahan Bali, sebagai telaah dan kajian yang memberikan rangsangan intuitif serta membangkitkan imajinasi kreatif dalam berolah seni untuk melahirkan keaslian karya seni (authenticity of the art work). Dalam kaitan ini distorsi dijadikan sebagai suatu teks, yang secara kontekstual diharapkan mampu menyikapi dan menjembatani segala isu dan problematik yang dihadapi masyarakat dunia saat ini, melalui karya seni lukis.

Visualisasi karya yang menyangkut teks maupun konteks, diartikulasikan ke dalam karya seni lukis melalui seleksi, rekonstruksi, elaborasi, dengan mengaplikasikan elemen/unsur-unsur seni rupa seperti: garis, warna, bentuk, tekstur, bidang/ruang. Elemen-elemen tadi tersusun dalam suatu komposisi yang utuh, tanpa mengabaikan unsur estetik, artistik serta harmoni, agar mencapai karya seni lukis yang individual simbolistik.

\section{DAFTAR PUSTAKA}

Atmaja, Jiwa. 2003. Perempatan Agung: Menguak Konsepsi Palemahan Ruang dan Waktu Masyarakat Bali. Denpasar: CV. Bali Media Adhikarsa.

Djelantik, A.A.M. 1990. Pengantar Ilmu Estetika: Estetika Instrumental.

Denpasar: Sekolah Tinggi Seni Indonesia Denpasar.

Hadi, Sumandyo Y. 2003. Mencipta Lewat Tari. Yogyakarta: Mantili. 
Driyarkara. 1980. Driyarkara Tentang Kebudayaan. Yogyakarta: Yayasan Kanisius.

Feldman, Edmund Burke. 1991. Seni Sebagai Ujud dan Gagasan. Terjemahan SP. Gustami. Yogyakarta: ISI Yogyakarta.

Ginarsa. 1979. Gambar Lambang. Denpasar: CV. Sumber Mas.

Hartoko, Dick. 1984. Manusia dan Seni. Yogyakarta: Kanisius.

Hooykaas, C. 1980. Drawings of Balinese Sorcery, Groningen Leiden: Institut of Religius Iconography State University.

Kartika, Sony Dharsono. 2004. Seni Rupa Modern. Bandung: Rekayasa Sains.

Nars, Seyyed Hossein. 1984. Antara Tuhan, Manusia dan Alam. Yogyakarta: IRCiSoD

Read, Herbert. 2000. Seni Arti dan Problematiknya. Terjemahan, Soedarso Sp. Yogyakarta: Duta Wacana University Press.

Sachari, Agus. 2000. "Riset Bidang Disain dan Kesenirupaan" dalam Refleksi Seni Rupa Indonesia. Jakarta: Balai Pustaka.

Sidik, Fadjar dan Aming Prayitno. 1979. Disain Elementer. Yogyakarta: STSRI ASRI

Soedarsono RM. 2001. Metodologi Seni Pertunjukan dan Seni Rupa. Bandung: Masyarakat Seni Pertunjukan Indonesia.

Soedarso SP. 1990. Tinjauan Seni: Sebuah Pengantar Untuk Apresiasi Seni. Yogyakarta: Saku Dayar Sana.

Sudharta, Tjok Rai. 2001. Upadesa: Tentang Ajaran-ajaran Agama Hindu. Surabaya: PARAMITA.

Sumardjo, Jakob. 2000. Filsafat Seni. Bandung: ITB

Sumartono. 1992. "Orisinalitas Karya Seni Rupa dan Pengakuan Intenasional" dalam SENI, Jurnal Pengetahuan dan Penciptaan Seni. BP ISI, Yogyakarta II/02. April 1992.

'Sunarya, I Ketut. 2004. "Konsep Rwa Bhineda Seni Kriya di Bali: Studi Kasus Ukiran Kayu Karya I Ketut Tulak". Tesis. Program Pascasarjana Institut Seni Indonesia Yogyakarta.

Sutrisno, Mudji SJ. 2004.' Ide-Ide Pencerahan., Jakarta: Yayasan Obor. Tedjoworo. 2001. Imaji dan Imajinasi: Suatu Telaah Filsafat Postmodern, Yogyakarta: Kanisius.

Titib, I Made. 2001. Teologi \& Simbol-Simbol dalam Agama Hindu. Surabaya: Badan Litbang Parisada Hindu Dharma Indonesia Pusat, PARAMITA.

Tucker, Mary Evelyn \& John A. Grim. 2003. Agama, Filsafat, \& Lingkungan Hidup, Yogyakarta: Kanisius.

Wisetrotomo, Suwarna. 1998. Melacak Garis Waktu dan Peristiwa. Jakarta: Departemen Pendidikan dan Kebudayaan, Jakarta.

\section{Lampiran 1: Bentuk-bentuk Rarajahan sebagi Sumber Inspirasi} Penciptaan Seni Lukis.

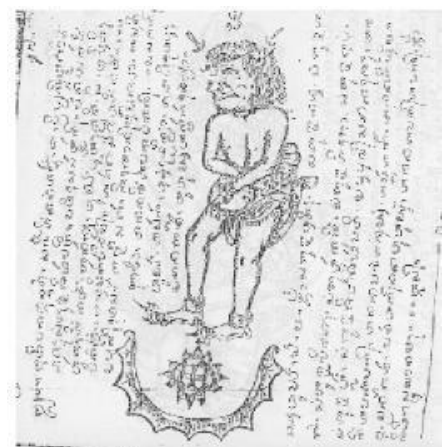

Gambar: 2 Rajah Penunggun KarangSebagai penolak bala/penjaga rumah tinggal (Sumber: Buku Rarajahan Bali/anonim,t.th.

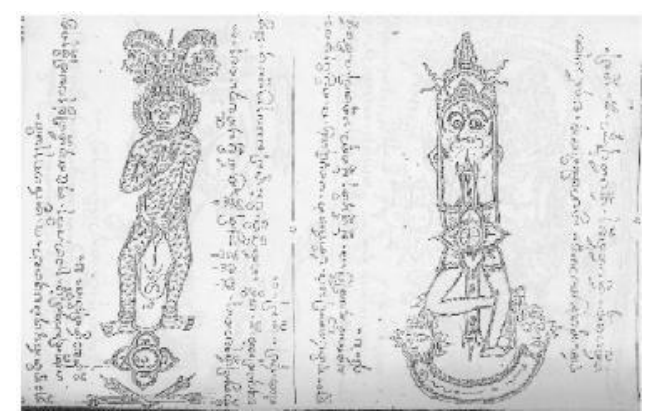

Gambar: 3 dan 4 Rajah Bhuta Kalednged dan Rajah Penungkul Agung Sebagai penolak bala dari serangan Leak dan penunggu rumah tinggal (Sumber: Buku Rarajahan Bali/anonim, t.th.)

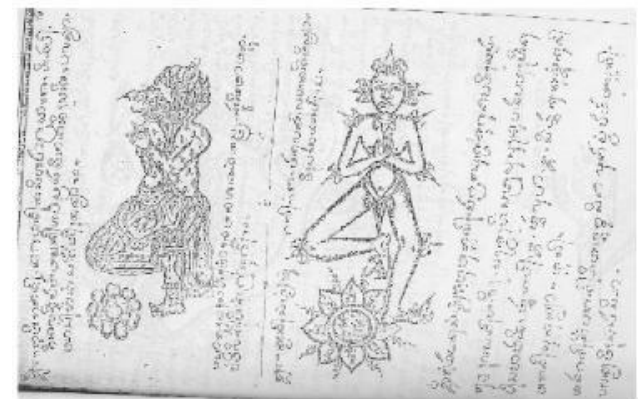

Gambar: 5 dan 6 Rajah Bagawan Kasiapa Gruda dan Sanghyang Tunggal Sebagai penyembuh segala penyakit dan penolak bahaya (Sumber: Buku Rarajahan Bali/ anonim,t.th). 


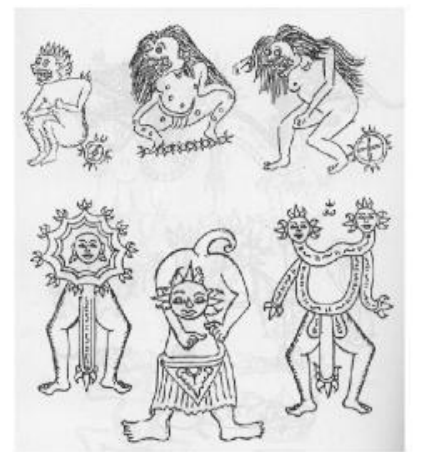

Gambar: 7 Rajah Bhuta Kala dengen Sebagai sarana melindungi pekarangan rumah (Sumber: Buku Drawings of Balinese Sorcery Oleh: Hooykaas, terjemahan, 1980, hal. 148.)

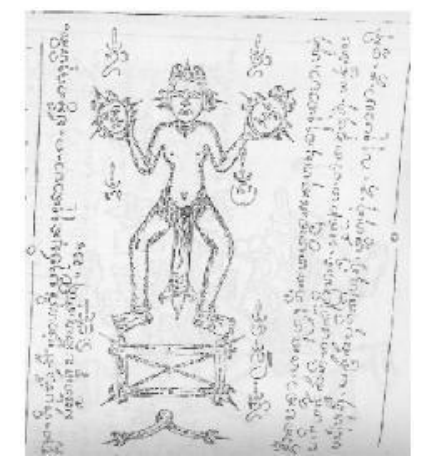

Gambar: 8 Rajah Penyengker wong agring muah pemunah dosa Sebagai penjaga orang yang sedang sakit dan menebus kesalahan (Sumber: Buku Rarajahan Bali/anonim, t.th.)

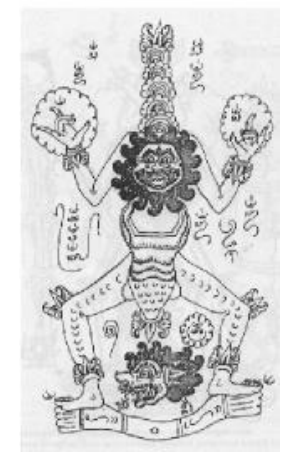

Gambar: 9 Rajah Kala Bang Kokah Sebagai penolak vampir dan senjata (Sumber: Buku Drawings of Balinese Sorcer, Hooykaas, terjemahan, 1980, hal. 136)

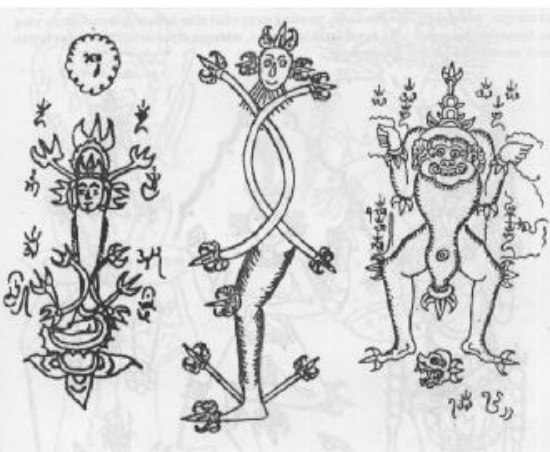

Gambar: 10 Rajah Dewa Singlar Sebagai alat untuk membingungkan musuh dan memberikan perlindungan, menghilangkan tikus, menghindarkan majik atas vampir, racun dan sebagainya (Sumber: Buku Drawings of Balinese Sorcery, Hooykaas,

$$
\text { terjemahan, 1980, hal. 141). }
$$

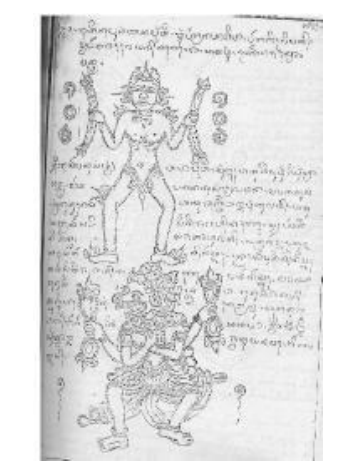

Gambar: 11 Rajah Kapusang Taya Murti Sebagai penakluk musuh (Sumber: Buku Rarajahan Bali/anonim,t.th.) 
Lampiran 2: Gambaran Tahapan-tahapan dalam Proses Perwujudan Karya Seni Lukis

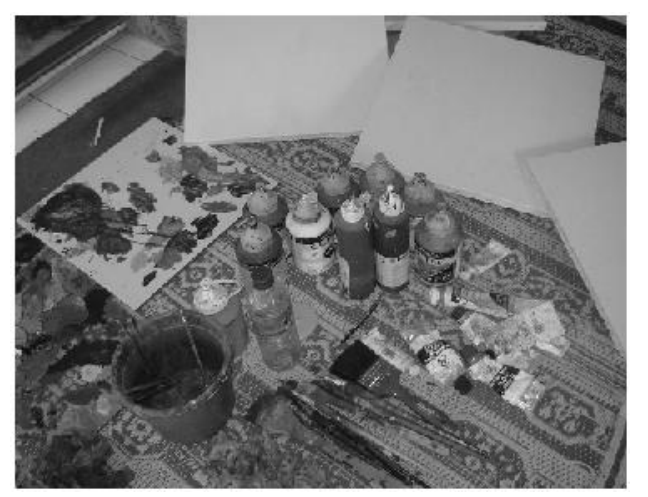

Bahan dan alat yang dipergunakan dalam proses perwujudan yakni: kanvas,cat akrilik, modeling paste, kuas dengan berbagai ukuran, pisau pallet, dan pallet pencampur warna dari kramik atau kaca.

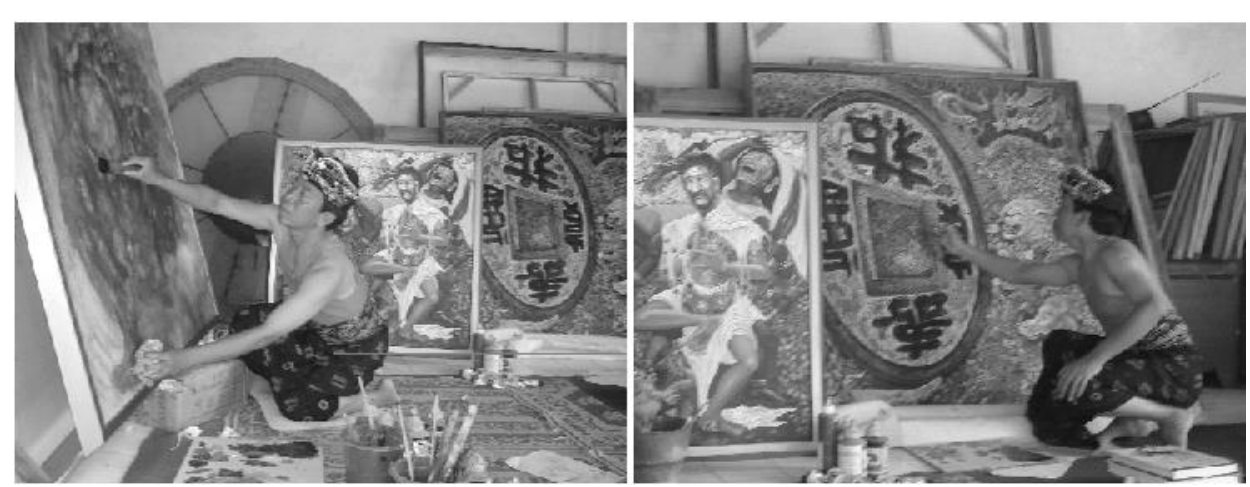

Membuat sketsa dengan goresan dan blok secara langsung pada kanvas dengan akrilik dan tahap finishing karya dengan mengisi detail-detail pada motif yang akan ditonjolkan 